Review

\title{
Causes, Consequences and Public Health Implications of Low B-Vitamin Status in Ageing
}

\author{
Kirsty Porter, Leane Hoey, Catherine F. Hughes, Mary Ward and Helene McNulty * \\ Northern Ireland Centre for Food and Health, Ulster University, Cromore Road, Coleraine BT52 1SA, UK; \\ porter-k7@email.ulster.ac.uk (K.P.); 1.hoey@ulster.ac.uk (L.H.); c.hughes@ulster.ac.uk (C.F.H.); \\ mw.ward@ulster.ac.uk (M.W.) \\ * Correspondence: h.mcnulty@ulster.ac.uk; Tel.: +44-28-7012-4583
}

Received: 15 September 2016; Accepted: 9 November 2016; Published: 16 November 2016

\begin{abstract}
The potential protective roles of folate and the metabolically related B-vitamins (vitamins B12, B6 and riboflavin) in diseases of ageing are of increasing research interest. The most common cause of folate and riboflavin deficiencies in older people is low dietary intake, whereas low B12 status is primarily associated with food-bound malabsorption, while sub-optimal vitamin B6 status is attributed to increased requirements in ageing. Observational evidence links low status of folate and the related B-vitamins (and/or elevated concentrations of homocysteine) with a higher risk of degenerative diseases including cardiovascular disease (CVD), cognitive dysfunction and osteoporosis. Deficient or low status of these B-vitamins alone or in combination with genetic polymorphisms, including the common MTHFR $677 \mathrm{C} \rightarrow$ T polymorphism, could contribute to greater disease risk in ageing by causing perturbations in one carbon metabolism. Moreover, interventions with the relevant B-vitamins to optimise status may have beneficial effects in preventing degenerative diseases. The precise mechanisms are unknown but many have been proposed involving the role of folate and the related B-vitamins as co-factors for one-carbon transfer reactions, which are fundamental for DNA and RNA biosynthesis and the maintenance of methylation reactions. This review will examine the evidence linking folate and related B-vitamins with health and disease in ageing, associated mechanisms and public health implications.
\end{abstract}

Keywords: B-vitamins; ageing; degenerative diseases; cardiovascular disease; cognitive dysfunction; dementia; osteoporosis; methylenetetrahydrofolate reductase (MTHFR)

\section{Introduction}

An estimated 900 million people are aged $\geq 65$ years globally, equating with $8 \%$ of the world's population, and by 2050, this is predicted to exceed two billion (16\%) [1]. Approximately one quarter of the total global burden of disease is in older people, with a higher prevalence in high income countries [2]. Hypertension, the leading risk factor of cardiovascular disease (CVD) affects an estimated one billion people worldwide and CVD is the most common cause of death in older people [3]. Globally, osteoporotic fractures affect over nine million older people annually [4], while 46.8 million older people are reported to have dementia worldwide [5]. The prevalence of these diseases of ageing is expected to substantially increase as a result of the ever-increasing ageing population. In addition, these degenerative diseases cause multiple co-morbidities in older people which in turn has important societal and economic consequences. Maintaining good health in older age has therefore become a major public health priority. Poor nutrition is recognised as a modifiable risk factor in the development of degenerative diseases in ageing, and improved nutrition may prevent or delay the onset of adverse health outcomes as people age. In this context, the potential adverse effect of elevated homocysteine and/or the protective roles of folate and the metabolically related B-vitamins (B12 and B6), have received much attention. 
This review will examine the emerging evidence linking folate and the metabolically related B-vitamins with ageing, the potential roles of these nutrients in preventing or delaying diseases of ageing and the associated mechanisms. The challenges and opportunities in achieving optimal B-vitamin status in older people will also be considered with particular emphasis on the role of food fortification.

\section{Metabolic Role of B-Vitamins in One-Carbon Metabolism}

Folate along with vitamins B12, B6 and riboflavin in their co-enzymatic forms are all essential in one-carbon metabolism (Figure 1), a network of reactions involving the transfer of one-carbon units. In the folate cycle, tetrahydrofolate obtains a carbon unit from serine in a vitamin B6 (plasma pyridoxal phosphate; PLP) dependent reaction forming 5,10-methylenetetrahydrofolate which is used for the synthesis of thymidine and purines or converted to 5-methyltetrahydrofolate. 5-methyltetrahydrofolate is the principal circulating form of folate, and this reaction is catalysed by methylenetetrahydrofolate reductase (MTHFR) using riboflavin (flavin adenine dinucleotide, FAD) as a co-factor. At this point, the folate cycle links with the methionine cycle, 5-methyltetrahydrofolate donates its methyl group to homocysteine for the formation of methionine in a reaction catalysed by methionine synthase which uses vitamin B12 (methylcobalamin) as a cofactor. Methionine is the precursor for S-adenosyl-methionine (SAM), the universal methyl donor for DNA and RNA, proteins and numerous central nervous system methylation reactions involving neurotransmitters, membrane phospholipid synthesis and myelin methylation [6,7]. SAM is converted to $S$-adenosylhomocysteine and then homocysteine which is either remethylated back to methionine or conversely metabolised in the transsulphuration pathway to form cysteine through another vitamin B6-dependent process [8]. The metabolism of the B-vitamins is closely related; folate and vitamin B12 are both intrinsically linked via the enzyme methionine synthase [9]. In vitamin B12 depletion, methionine synthase activity is reduced and the formation of tetrahydrofolate is blocked, with folate essentially becoming trapped as 5-methyltetrahydrofolate because the conversion by MTHFR is physiologically irreversible [10]. There is also an important metabolic inter-relationship between vitamin B6 and riboflavin. The conversion of dietary vitamin B6 in tissues to its functional enzyme, pyridoxal 5' phosphate (PLP), requires the enzyme pyridoxine phosphate oxidase (PPO), which is dependent on the riboflavin in its co-factor form, flavin mononucleotide (FMN).

Deficiencies in any of these B-vitamins can perturb the complex regulatory network maintaining one-carbon metabolism resulting in reduced methylation status within the relevant tissue, hyperhomocysteinemia, and/or increased misincorporation of uracil into DNA as a result of thymidylate synthesis being impaired owing to low 5,10-methylene-THF concentrations and thus uracil is inserted instead during DNA synthesis which in turn may contribute to adverse health outcomes in ageing [11,12]. In addition, genetic polymorphisms, including the common $677 \mathrm{C} \rightarrow \mathrm{T}$ polymorphism in the gene encoding the folate-metabolising enzyme MTHFR, can interact adversely with sub-optimal status of one or more of the B-vitamins in one-carbon metabolism and thus contribute to a greater disease risk [13]. The MTHFR 677TT genotype affects an estimated $10 \%$ of individuals worldwide (ranging from $3 \%$ to $32 \%$ depending on ethnicity) [14] and $12 \%$ in Ireland [15]. 


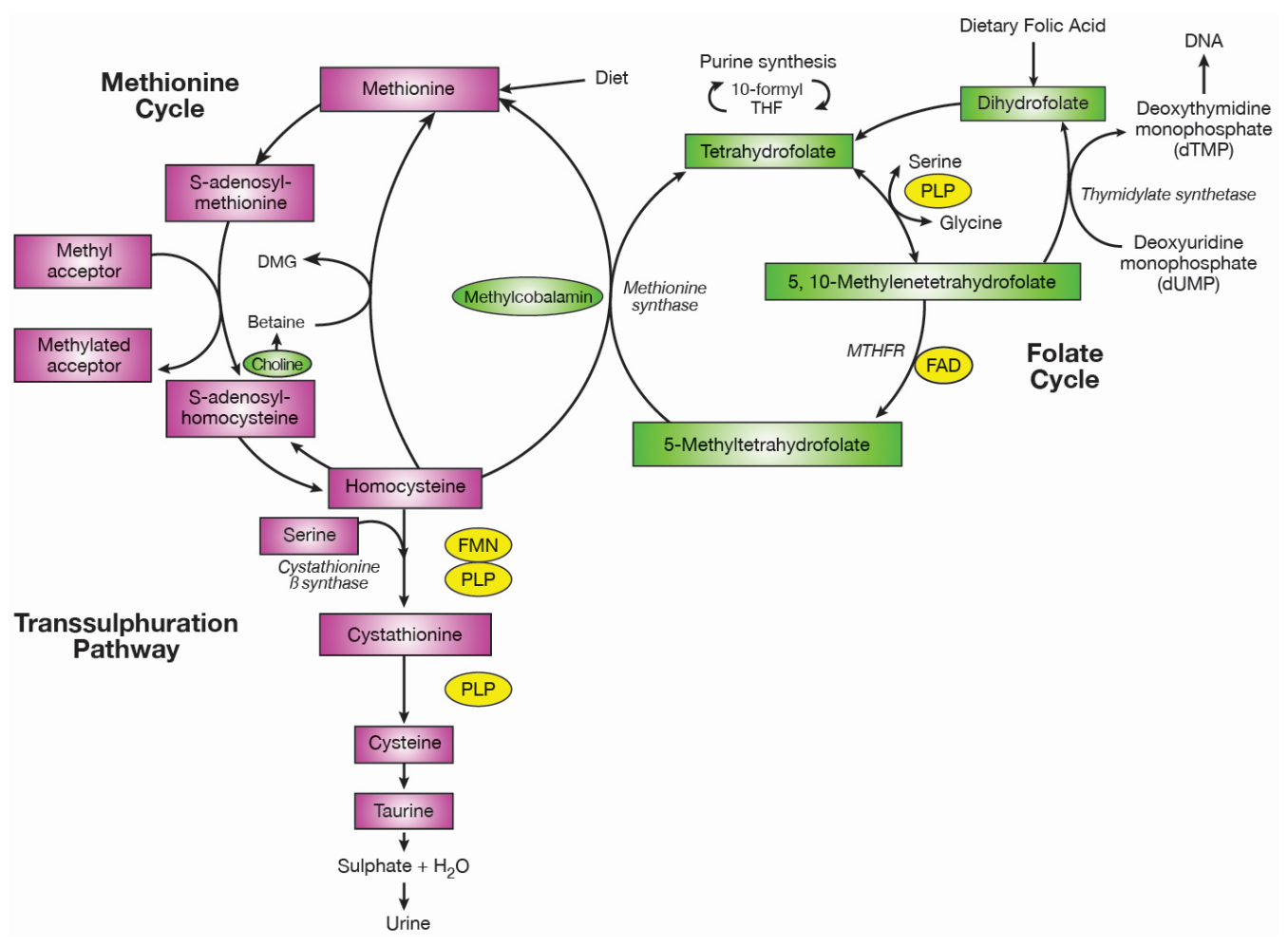

Figure 1. One-carbon metabolism. Abbreviations: PLP, plasma pyridoxal phosphate; MTHFR, methylenetetrahydrofolate reductase; FAD, flavin adenine dinucleotide; FMN, flavin mononucleotide. Adapted from [16].

\section{Causes of B-Vitamin Deficiency}

Depending on the particular vitamin, there are a number of potential causes of B-vitamin deficiency including inadequate intake, increased requirements, malabsorption, drug-nutrient interactions and others including genetic disorders or medical conditions (Table 1). In addition, the ageing process itself can negatively affect the absorption, transport and metabolism of B-vitamins and thus older people have increased requirements. A recent systematic review in community dwelling older adults in developed Western countries $(n=28,000)$ reported a high prevalence of low dietary intakes for B-vitamins (i.e., below the estimated average requirement, EAR), including folate $(29 \%-35 \%)$, vitamin B6 (24\%-31\%) and identified riboflavin (31\%-41\%) among six nutrients of potential public health concern [17]. An estimated $9 \%-12 \%$ of older people in the UK are considered to suffer from folate deficiency [18], with the most common cause being low dietary intake. 
Table 1. Causes of B vitamin deficiency.

\begin{tabular}{|c|c|c|c|c|c|}
\hline B Vitamin & Inadequate Intake & Increased Requirement & Malabsorption & Drug-Nutrient Interactions & Other \\
\hline Folate [19-24] & $\begin{array}{l}\text { Common } \\
\text { Poor cooking techniques }\end{array}$ & $\begin{array}{l}\text { Elderly } \\
\text { Pathological conditions }\end{array}$ & $\begin{array}{l}\text { Intestinal diseases } \\
\text { Coeliac disease } \\
\text { Crohn's disease } \\
\text { Ulcerative Colitis }\end{array}$ & $\begin{array}{l}\text { Phenytoin } \\
\text { Phenobarbital/Primidone } \\
\text { Trimethoprim } \\
\text { Methotrexate } \\
\text { Sulfasalazine } \\
\text { Metformin }\end{array}$ & $\begin{array}{l}\text { Alcohol abuse } \\
\text { Genetic disorders } \\
\text { Haemolytic anaemia }\end{array}$ \\
\hline B12 $[19,21,22,25,26]$ & $\begin{array}{l}\text { Common } \\
\text { Vegan diets }\end{array}$ & Elderly & $\begin{array}{l}\text { Intestinal diseases } \\
\text { Coeliac disease } \\
\text { Crohn's disease } \\
\text { Gastric/intestinal resection } \\
\text { Atrophic gastritis } \\
\text { Bacterial overgrowth } \\
\text { Helicobacter pylori } \\
\text { Pancreatic insufficiency } \\
\text { Pernicious anaemia } \\
\text { Zollinger-Ellison Syndrome }\end{array}$ & $\begin{array}{l}\text { Proton pump inhibitors } \\
\text { H2-receptor antagonists } \\
\text { Metformin } \\
\text { Nitrous oxide } \\
\text { Colchicine }\end{array}$ & $\begin{array}{l}\text { Alcohol abuse } \\
\text { Genetic disorders } \\
\text { Tropical or non-tropical sprue }\end{array}$ \\
\hline B6 $[21,22,25,26]$ & $\begin{array}{l}\text { Rare } \\
\text { Chronic dieters }\end{array}$ & Elderly & HIV & $\begin{array}{l}\text { Isoniazid } \\
\text { Anti-Convulsants } \\
\text { Steroids }\end{array}$ & $\begin{array}{l}\text { Alcohol abuse } \\
\text { Genetic disorders } \\
\text { Liver disease } \\
\text { Renal dialysis } \\
\text { Rheumatoid arthritis }\end{array}$ \\
\hline B2 [21,25-27] & $\begin{array}{l}\text { Common } \\
\text { Chronic dieters }\end{array}$ & Elderly & $\begin{array}{l}\text { Diabetes } \\
\text { Liver disease } \\
\text { Thyroid and renal insufficiency } \\
\text { GI and biliary obstruction }\end{array}$ & $\begin{array}{l}\text { Phenothiazines, e.g., } \\
\text { chlorpromazine } \\
\text { Theophylline }\end{array}$ & $\begin{array}{l}\text { Alcohol abuse } \\
\text { Genetic disorders } \\
\text { Hypochromic anaemia } \\
\text { Metals such as zinc, copper and iron }\end{array}$ \\
\hline
\end{tabular}


There is a high prevalence of vitamin B12 deficiency in older people globally [28], with two early studies finding $75 \%$ of Asian Indians demonstrating metabolic evidence of vitamin B12 deficiency $[29,30]$. Numerous population surveys have also identified varying levels of vitamin B12 deficiency and sub-optimal status in older people from the UK (5\%-20\% deficient) [31-33], US ( $6 \%$ deficient, $>20 \%$ marginal status) [34,35] Canada (5\% deficient) [36], New Zealand (12\% deficient, $28 \%$ marginal deficiency) [37] and Finland (6\% low B12 and 32\% borderline) [38]. The variation in prevalence may in part be explained by the diagnostic criteria used and different studies have used different biomarkers and cut off points. Pernicious anaemia, the classic form of B12 deficiency, caused by a lack of intrinsic factor is thought to account for just $1 \%-2 \%$ of cases of insufficiency in older people [39]. The maintenance of vitamin B12 status in older people is not only dependent on adequate dietary intake but more critically on the normal absorption of the vitamin which is dependent on the normal functioning of the gastrointestinal tract, gastric acid secretion and a number of transport proteins including intrinsic factor [40]. Food-bound malabsorption, primarily as a result of atrophic gastritis, an age-related disorder affects up to $30 \%$ of older people [41], leads to a reduction in gastric acid secretion which prevents the release of B12 from food and thus absorption. Deficiency is less pronounced and the limitations of the conventional vitamin B12 assays may also mean that a significant proportion of the older population may have low vitamin B12 status which is not detected $[40,42]$.

Medications including proton pump inhibitors (PPI) and H2-receptor antagonists $\left(\mathrm{H}_{2} \mathrm{RA}\right)$ are commonly prescribed (for conditions such as reflux and peptic ulcers) in older people, resulting in gastric acid suppression, this mimics atrophic gastritis and leads to food-bound malabsorption. There is evidence to suggest that these medications have been associated with up to 4.5 times higher risk of vitamin B12 deficiency in case control studies [43,44]. Recently in the USA, a large community survey (25,956 cases and 184,199 controls) found that the long term use ( $>2$ years) of $\mathrm{H}_{2}$ RAs and PPIs was associated with a $25 \%-65 \%$ greater risk of a subsequent diagnosis of vitamin B12 deficiency [45]. In addition, metformin usage in Type 2 Diabetes can also result in vitamin B12 deficiency, possibly interfering with calcium-dependent membrane action in the terminal ileum required for the absorption of the vitamin B12-intrinsic factor complex [46,47].

Vitamin B6 and riboflavin in older people have not been as widely investigated. There is a high prevalence of vitamin B6 deficiency in older people as evident in three large population based surveys in Europe (Survey in Europe Nutrition and the Elderly, a Concerted Action, SENECA; 23\%) [48], the UK (National Diet and Nutrition survey; NDNS; $11 \%-27 \%$ free living, 30\%-65\% institutionalised) [49], and the US (National Health and Nutrition Examination Survey, NHANES; $15 \%-23 \%$ males, $14 \%-49 \%$ females) [50] This deficiency in older age has been attributed to increased requirements as a result of reduced absorption, increased catabolism and impaired phosphorylation as opposed to inadequate dietary intake [51,52].

Riboflavin deficiency is thought to mainly arise from inadequate dietary intake, particularly in those who do not consume dairy products or fortified foods $[17,27,53]$. A high prevalence of riboflavin deficiency is acknowledged in the developing world; less well recognised is the emerging evidence to suggest that sub-optimal status is also evident in developed countries. To date, most population based surveys only report dietary intake data, and relatively few include biomarker data. Despite dietary intakes being reported to be sufficient in the NDNS (5\% below reference nutrient intake, RNI) [54] and in the Irish National Adult Nutrition Survey (NANS, 13\% below EAR) [55], 39\%-43\% of older people had biochemical deficiency in the NDNS and 19\%-22\% in NANS. Thus, further population based surveys are still required to investigate the intake and requirements of older people based on robust biomarker data of both vitamin B6 and riboflavin.

\section{Assessment of B-Vitamin Biomarker Status}

There are a number of direct and functional biomarkers available to determine B-vitamin status each with various strengths and limitations (Table 2). Plasma homocysteine accumulates with folate deficiency, it has been used as a biomarker of status but it lacks specificity as it can also be elevated by 
other B-vitamin deficiencies, including vitamins B12 [56], B6 [57] and riboflavin [58]. Serum folate is the earliest indicator of altered folate exposure and reflects recent dietary intake [59]. Red blood cell (RBC) folate is a sensitive indicator of long term folate status (during the preceding 120 days) [60,61]. It parallels liver concentrations this is considered to reflect tissue folate stores [20,62]. One recent meta-analysis demonstrated that both serum folate (27 RCTs) and RBC folate (12 RCTs) respond to interventions with folic acid in a dose-dependent manner and concluded that both indicators were robust measures of folate status [63]. To date, there is no gold standard biomarker for the assessment of vitamin B12 status despite there being a number of direct and functional measures available. Serum B12, although still widely used both clinically and in research, measures the total amount of the vitamin, however only $20 \%$ of this is metabolically active [64]. Serum total vitamin B12 can under-report the true prevalence of vitamin B12 deficiency $[65,66]$ and up to $40 \%$ of older people can have low serum vitamin B12 but normal metabolic status $[41,67]$. Holo-transcobalamin (holoTC) measures the biologically active fraction of vitamin B12 and is considered to have superior diagnostic value to total B12 [68,69] although it can be affected by inborn errors altering intracellular vitamin B12 metabolism [68]. Plasma homocysteine can be used as a functional measure of vitamin B12 status but as previously discussed it is not specific to vitamin B12 (Table 2). Methylmalonic acid (MMA) is a more specific and sensitive functional biomarker of vitamin B12 status [31], the conversion of methylmalonyl-CoA to succinyl-CoA is a B12 dependant process, impaired B12 status leads to an accumulation of methymalonyl-CoA which then is metabolised to MMA and excreted in the urine. However, MMA is also elevated in renal dysfunction, which is common in older people [69] and so limits its use. Two reviews have recommended that at least 2 biomarkers are required in the diagnosis of vitamin B12 deficiency [42,70].

Plasma PLP concentration is the most widely used measure of vitamin B6 [71] with good specificity [72]. It is considered to reflect PLP concentrations in the liver [73]. Other markers of B6 are available including 4-pyridoxic acid and erythrocyte pyridoxal-5-phosphate. Erythrocyte glutathione reductase activation (EGRac) assay is the most widely used functional assay for riboflavin status and is generally regarded as the gold standard. EGRac measures glutathione reductase activity in erythrocytes before and after reactivation with its prosthetic group flavin adenine dinucleotide (FAD). A systematic review (14 RCTs) concluded that EGRac was a sensitive biomarker of change in riboflavin intake in populations with status ranging from deficient to normal [74].

In general, the use of different biomarkers or different cut off points for defining deficiency/suboptimal status when assessing individual B-vitamins can influence the interpretation and conclusion of relevant studies. This can make direct comparisons among studies difficult and may explain some inconsistencies in the literature as regards the role of B-vitamins in diseases in ageing. 
Table 2. Assessment of B-vitamin biomarker status.

\begin{tabular}{|c|c|c|c|c|}
\hline & & Biomarker & Strengths & Limitations \\
\hline Homocysteine [20] & Functional & Plasma homocysteine & $\begin{array}{l}\text { Sensitive functional biomarker } \\
\text { Highly responsive to intervention with B-vitamins } \\
\text { Responds within } 3-4 \text { weeks of B-vitamin depletion and } \\
\text { subsequent repletion } \\
\text { Very stable analyte } \\
\text { Can be stored frozen for extended periods of time } \\
\end{array}$ & $\begin{array}{l}\text { Lacks specificity as affected by other B-vitamins } \\
\text { Requires separation from RBCs within one hour of blood } \\
\text { collection, or }<8 \mathrm{~h} \text { if whole blood is kept on ice } \\
\text { Influenced by other factors such as lifestyle, genetics, renal } \\
\text { insufficiency, age and medications }\end{array}$ \\
\hline \multirow{2}{*}{ Folate $[20,21,60,63,75]$} & \multirow[t]{2}{*}{ Direct } & Serum/Plasma folate & $\begin{array}{l}\text { Earliest indicator of altered folate exposure } \\
\text { Reflects recent dietary folate intake } \\
\text { Requires less time processing at time of blood collection vs. RBC folate } \\
\text { Can be measured in the field }\end{array}$ & $\begin{array}{l}\text { Inconsistent use of cut off values makes comparisons across } \\
\text { different methods and labs difficult } \\
\text { Fasting blood samples are recommended }\end{array}$ \\
\hline & & Red cell folate & $\begin{array}{l}\text { Sensitive indicator of long-term folate status } \\
\text { Reflects folate status over half-life of RBCs } \\
\text { Reflects tissue folate stores as parallels liver concentrations } \\
\text { Highly correlated with habitual intake when expressed as DFEs }\end{array}$ & $\begin{array}{l}\text { Affected by vitamin B12 deficiency } \\
\text { Inconsistent use of cut off values makes comparisons across } \\
\text { different methods and labs difficult } \\
\text { Cannot be measured in the field }\end{array}$ \\
\hline \multirow[t]{3}{*}{ B12 $[21,34,60,70,75,76]$} & \multirow[t]{2}{*}{ Direct } & Serum/Plasma total B12 & $\begin{array}{l}\text { Serum standard clinical test } \\
\text { Variety of assays available } \\
\text { Measures all forms of vitamin B12 }\end{array}$ & $\begin{array}{l}\text { Does not reflect intracellular vitamin B12 } \\
\text { Falsely elevated B12 caused by factors including liver } \\
\text { disorders, bacterial overgrowth, renal failure } \\
\text { Falsely low B12 caused by factors such as iron deficiency, } \\
\text { HIV infection and pregnancy } \\
\text { Inconsistent use of cut off values makes comparisons across } \\
\text { different methods and labs difficult }\end{array}$ \\
\hline & & $\begin{array}{l}\text { Serum/Plasma } \\
\text { Holo-transcobalamin } \\
\text { (HoloTC) }\end{array}$ & $\begin{array}{l}\text { Represents metabolically active fraction of B12 } \\
\text { Decrease in holoTC can indicate earliest sign of B12 depletion } \\
\text { Considered better indicator of B12 status in elderly }\end{array}$ & $\begin{array}{l}\text { Highly sensitive to altered renal function and influenced by } \\
\text { factors including genetics }\end{array}$ \\
\hline & Functional & $\begin{array}{l}\text { Serum/plasma/urine } \\
\text { Methylmalonic acid } \\
\text { (MMA) }\end{array}$ & $\begin{array}{l}\text { Reflects availability of intracellular B12 } \\
\text { Early detection of functional B12 deficiency } \\
\text { Not affected by folate deficiency }\end{array}$ & $\begin{array}{l}\text { Lacks sensitivity as can be elevated in those with } \\
\text { renal impairment } \\
\text { High running costs }\end{array}$ \\
\hline
\end{tabular}


Table 2. Cont.

\begin{tabular}{|c|c|c|c|c|}
\hline & & Biomarker & Strengths & Limitations \\
\hline \multirow[t]{2}{*}{ B6 $[21,60,72,77,78]$} & Direct & $\begin{array}{l}\text { Plasma } \\
\text { Pyridoxal-Phosphate } \\
\text { (PLP) }\end{array}$ & $\begin{array}{l}\text { Most widely used } \\
\text { Good specificity and reflects PLP content in liver } \\
\text { Responds quickly within } 1-2 \text { weeks of B6 depletion and } \\
\text { subsequent repletion } \\
\text { Reference ranges available for younger and older adults } \\
\text { Fairly stable at low temperatures }\end{array}$ & $\begin{array}{l}\text { Does not represent PLP content in the muscle which is } \\
\text { resistant to B6 depletion } \\
\text { Influenced by other factors such as age, sex, pregnancy, } \\
\text { protein and alcohol intake } \\
\text { PLP declines in samples stored at room temperature and } \\
\text { exposure to light } \\
\text { Fasting blood samples are recommended } \\
\text { Plasma PLP concentrations affected by use of certain drugs }\end{array}$ \\
\hline & & Erythrocyte PLP & $\begin{array}{l}\text { Positively correlated with B6 dietary intake } \\
\text { Responds within weeks of B6 depletion and subsequent repletion } \\
\text { Appears more responsive than plasma PLP to supplementation } \\
\text { May be more reliable marker than plasma PLP under conditions and } \\
\text { disease associated with inflammation }\end{array}$ & $\begin{array}{l}\text { Affected by haemoglobin variants } \\
\text { Assay is cumbersome, with variable recovery and } \\
\text { low precision }\end{array}$ \\
\hline \multirow[t]{2}{*}{ B2 $[21,60,74,78]$} & Direct & $\begin{array}{l}\text { Serum/Plasma/Erythrocyte } \\
\text { Riboflavin/Flavine } \\
\text { Adenine Dinucleotide } \\
\text { (FAD)/Flavin } \\
\text { Mononucleotide (FMN) }\end{array}$ & $\begin{array}{l}\text { Riboflavin vitamers are stable for several years when plasma samples } \\
\text { are stored at }-80^{\circ} \\
\text { CSerum/plasma can be used retrospectively in a hospital setting }\end{array}$ & $\begin{array}{l}\text { Influenced by other factors such as age, sex, pregnancy, } \\
\text { protein and alcohol intake } \\
\text { Serum/plasma riboflavin concentrations affected by use of } \\
\text { certain drugs } \\
\text { High variability within and between-subjects compared to } \\
\text { the cofactor forms of riboflavin (plasma/erythrocyte) }\end{array}$ \\
\hline & Functional & $\begin{array}{l}\text { Erythrocyte glutathione } \\
\text { reductase activation } \\
\text { (EGRac) assay }\end{array}$ & $\begin{array}{l}\text { Most widely used marker of status } \\
\text { Measures tissue saturation and long term status } \\
\text { Enzyme is stable for several years when erythrocyte lysates are } \\
\text { stored at }-80^{\circ} \mathrm{C}\end{array}$ & $\begin{array}{l}\text { Poor index of optimum riboflavin status } \\
\text { Assay is not linear against status } \\
\text { Difficult make comparisons across different methods } \\
\text { and labs }\end{array}$ \\
\hline
\end{tabular}




\section{Consequences of B-Vitamin Deficiency}

There are established clinical signs of B-vitamin deficiency (Table 3). The haematological manifestation of folate and vitamin B12 deficiency is indistinguishable, as both vitamins are linked through the enzyme methionine synthase [9] which catalyses the remethylation of homocysteine to methionine and thus are metabolically interrelated [79]. Deficiency of either vitamin results in a reduction of the active form of folate which subsequently results in megaloblastic anaemia [80], characterised by megaloblasts in the bone marrow, macrocytes in the peripheral blood and gigantism in the morphology of proliferating cells [25]. Vitamin B12 deficiency can also result in diverse neurological symptoms including irreversible nerve damage and sub-acute combined degeneration of the spinal cord if left untreated, as patients are often asymptomatic [81]. Neuropathy is quite specific to vitamin B12 and does not occur in folate deficiency [79]. Although severe vitamin B6 deficiency is relatively uncommon, it can present with notable symptoms such as anaemia, depression and sores or ulcers of the mouth [22]. The classical signs of riboflavin deficiency are angular stomatitis, cheilosis and glossitis, but these are rarely encountered in isolation and may be as a result of other B-vitamin deficiencies [27].

Apart from clinical deficiency signs, deficient or low status of B-vitamins can be associated with various adverse health outcomes throughout the lifecycle [82]. It should be noted that these can arise in the absence of more classical deficiency signs, and can occur within the range of what may be classed as "normal" within the clinical setting.

Table 3. Consequences of deficient or low status of B-vitamins.

\begin{tabular}{ll}
\hline & Clinical Deficiency Signs [19-22] \\
\hline Folate & Megaloblastic anaemia, clinical features characterised by \\
& megaloblasts in the bone marrow \\
& macrocytes in the peripheral blood \\
& gigantism in the morphology of proliferating cells \\
& Megaloblastic anaemia \\
indistinguishable from folate-related megaloblastic anaemia \\
Irreversible nerve damage/neuropathy \\
Sub-acute combined degeneration of the spinal cord (SCD) \\
Notable symptoms include: \\
Microcytic anaemia \\
Inflammation of the tongue \\
Sores or ulcers of the mouth \\
Dermatitis \\
Nervous/muscular signs \\
Irritability, fatigue, numbness \\
Headache, muscle twitching \\
Difficulty walking, convulsions \\
Depression and confusion \\
Classic signs arbioflavinosis, rarely encountered in isolation \\
Anaemia \\
Cheliosis, Angular stomatitis \\
Glossitis \\
Redness and swelling of the lining of the mouth and throat \\
Seborrheic dermatitis particularly affecting the nose, cheeks and forehead \\
Eyes burning and itching \\
Sensitivity to light \\
Loss of visual acuity \\
Gritty sensation under the eyelids \\
Health Consequences of Low Status of Folate and/or Other B-Vitamins [83-89] \\
Elevated homocysteine \\
CVD and stroke \\
Cognitive decline/dementia/Alzheimer's \\
Osteoporosis and risk of fractures \\
\hline \\
B2
\end{tabular}




\section{Emerging Roles of B-Vitamin Status in Preventing Diseases of Ageing}

\subsection{Cardiovascular Health in Ageing}

Clinical evidence has linked elevated plasma homocysteine concentrations and/or low folate with an increased risk of CVD. Early meta-analyses of observational studies concluded that lowering homocysteine would reduce the risk of heart disease by $11 \%-16 \%$ [83,84]. Homocysteine may however be a marker of suboptimal B-vitamin status and thus simply reflect a perturbation in one-carbon metabolism, rather than playing a causative role in CVD, but this is not universally accepted [90]. In any case, several secondary prevention randomised controlled trials (RCTs) published between 2004 and 2012 have failed to demonstrate a benefit of homocysteine-lowering by B-vitamin supplementation on CVD events generally [91-97]. These studies, however, typically involved patients with existing optimal B-vitamin status and/or advanced CVD, and thus a significant effect of B-vitamin supplementation on CVD risk may have been unlikely.

The evidence however is generally much stronger for stroke than heart disease, with meta-analyses of earlier observational studies concluding that lowering homocysteine would reduce the risk of stroke by $19 \%-24 \%[83,84]$. Furthermore, population data from the USA and Canada, reported an improvement in stroke mortality corresponding to the time that mandatory food fortification was introduced; in contrast, no similar improvement was found over the same time period in England and Wales where no mandatory fortification policy exists [98]. Of greatest relevance however are the findings of RCTs in relation to stroke risk, with meta-analyses of folic acid interventions showing a reduced risk of stroke by $18 \%$ overall [99], but with much greater reductions in risk noted in studies with longer folic acid treatment duration, with greater homocysteine reduction and in particular in those with no history of stroke $[99,100]$. More recent evidence including the China Stroke Primary Prevention Trial (CSPPT) [101] and a meta-analysis of 30 RCTs [102] also support a significant beneficial effect of folic acid supplementation on CVD risk (especially stroke), particularly in those with lower baseline folate status and without pre-existing CVD. Thus, optimisation of folate and the related B-vitamins might be beneficial in lowering CVD risk, particularly stroke, and most convincingly in primary prevention.

In addition, genetic studies are now providing stronger evidence for the potential role of folate and the related B-vitamins in CVD, primarily through the investigation of the common $677 \mathrm{C} \rightarrow \mathrm{T}$ polymorphism in the gene encoding the folate-metabolising enzyme MTHFR. Epidemiological evidence suggests that this common polymorphism increases the risk of CVD, especially stroke by up to $40 \%$ overall [84,103-105]. Furthermore, evidence is emerging to suggest that the excess genetic risk of CVD may be driven by higher blood pressure (rather than higher homocysteine), with meta-analyses of observational studies showing that the MTHFR $677 \mathrm{C} \rightarrow \mathrm{T}$ polymorphism increases the risk of hypertension by $36 \%-87 \%[106,107]$. This is also supported by recent evidence from a large study of Irish adults $(n=6069)$, which estimated that the MTHFR 677TT genotype was associated with an almost two-fold increased hypertension risk, a risk which was further increased when the genotype occurred in combination with low riboflavin status [15]. In addition, intervention studies from this centre, conducted in participants with premature CVD or hypertension showed that those with the MTHFR 677TT genotype were highly responsive to blood-pressure lowering through riboflavin supplementation, whilst no response was observed in participants with CC or CT genotypes [108-110]. Therefore, sub-populations worldwide with the MTHFR 677TT genotype (ranging from 3\% to 32\%) [14], may particularly be at greater risk of CVD via a blood pressure effect, and could benefit from a more optimal riboflavin status ideally before hypertension has developed.

\subsection{Bone Health in Ageing}

The role of B-vitamins in bone health has been extensively reviewed [16]. Briefly, observational evidence in older people has found independent associations of elevated homocysteine with bone mineral density (BMD) $[111,112]$ and fracture risk $[89,113]$. Meta-analyses of observational studies 
have confirmed these relationships, with one $(n=14,863)$ concluding that homocysteine was an independent risk factor [114]. Another dose response meta-analysis $(n=11,511)$ estimated a $4 \%$ increased fracture risk for every $1 \mu \mathrm{mol} / \mathrm{L}$ increase of homocysteine concentration [115]. Low BMD has also been associated with sub-optimal status or dietary intakes of folate $[111,116]$ or vitamin B12 [112,117]. Likewise, studies have also found an increased fracture risk in older people with sub-optimal status/intake of folate [118], vitamin B12 [119,120], or vitamin B6 [121,122]. Only one study to date in coeliac patients $(n=110)$ has examined riboflavin biomarker status with bone health (BMD), and found no relationship [16]. Although, low riboflavin intake in women (aged $\geq 55$ years, $n=5035$ ) was associated with a 1.8 times increased risk of osteoporotic facture and 2.6 times increased risk of fragility fractures [119]. The evidence is not entirely consistent, however, as some observational studies have shown no relationships with B-vitamin biomarkers on BMD [123] or fracture risk [124]. To date, there is limited RCT evidence linking B-vitamins with bone health and disease. One notable two-year RCT of combined folic acid and vitamin B12 supplementation $(n=628)$ resulted in a $75 \%$ reduction in the risk of hip fractures in older post-stroke Japanese patients, with low baseline folate status [125]. Certain RCTs with B-vitamins, which are not designed to examine bone outcomes (but rather other health outcomes), have reported no significant associations with fracture risk [126,127]. Additionally, interventions involving participants with generally higher baseline folate status have also reported no significant associations with BMD [128] or fracture risk [129]. This suggests that the benefit of interventions with B-vitamins may be confined to at-risk groups such as those with sub-optimal status.

Genetic studies also support the potential role of folate and the related B-vitamins in bone health. The potential influence of MTHFR 677TT polymorphism on bone health may be mediated through impaired DNA methylation as a result of impaired DNA structure and stability [130,131], expression and the silencing of genes [132-134]. Epidemiological studies have reported that the MTHFR 677TT genotype is associated with significantly lower BMD $[135,136]$ and a 2- to 2.5 -fold increased risk of fractures [135,137]. This is also strengthened by one meta-analysis ( 3525 cases and 17,909 controls) which concluded that the MTHFR $677 \mathrm{C} \rightarrow$ T polymorphism was associated with BMD at multiple sites and individuals with the TT genotype had a $23 \%$ increased risk of all fractures [138]. Furthermore, the association appears to be influenced by prevailing B-vitamin intake, an interaction between the MTHFR 677TT genotype and low intakes of folate or riboflavin has been linked with lower BMD [139-141], higher bone loss and up to a three-fold increased fracture risk [118,142], although the majority of these studies do not consider B-vitamin biomarker status. This suggests that individuals with the MTHFR 677TT genotype and low B-vitamin status may be most vulnerable to poor bone health in later life.

\subsection{Brain Health in Ageing}

\section{Cognitive Dysfunction}

Cognitive dysfunction ranges from mild cognitive impairment (MCI) to dementia and can result in a progressive loss of a number of specific cognitive functions $[143,144]$. The rate of cognitive decline varies between individuals [145], and it is estimated that $50 \%$ of older people with MCI will go on to develop dementia within five years of diagnosis [146]. Dementia has a number of distinct pathologies, although mixed pathologies in individuals have been shown at brain autopsies $[147,148]$. These include reduced/blocked flow to the brain [149], neuronal loss and damage to the connection between neurones [150] and the presence of Lewy bodies which has also been associated with neurotransmitter depletion [151]. Extra-neuronal $\beta$ amyloid plaques and intra-neuronal neurofibrillary tangles [152] can also be present. Brain atrophy is a normal part of the ageing process, but with dementia, the rate is significantly higher overall and particularly in the hippocampus region [153,154]. Grey and white matter loss, thinning of cortical gyri and enlarged ventricles can also be evident in those with dementia [155]. 
Prospective studies make a strong case for elevated homocysteine and/or low B-vitamin status as potential causative factors in cognitive decline [156,157] and dementia [85]. This is further supported by three recent reviews and meta-analyses $[87,158,159]$. Epidemiological studies have also investigated the role of the relevant B-vitamins, with the focus mainly on folate and vitamin B12. Studies involving populations with lower baseline folate status in general support the role of folate in cognitive dysfunction [160-162] and cognitive decline [163,164], whereas those in countries with food fortification policies and thus overall higher mean concentrations of folate, are generally less supportive for a role in cognitive dysfunction [165,166], cognitive decline [167-169] or dementia [170]. Similarly, a number of large cohort studies have associated low vitamin B12 status (using more sensitive biomarkers of status including MMA and HoloTC) with cognitive dysfunction $[160,166,171]$ and cognitive decline $[162,172,173]$ in older people. However, the evidence for B12 is less convincing, and one meta-analysis has shown no association of vitamin B12 with cognitive decline or dementia $(n=14,325)$ [174]. This lack of significant association for B12 may be explained the fact that some of the included studies had methodological shortcomings (including limitations in the biomarkers used to determine B12 status). Thus, when sub-analysis of the data was carried out based on studies using more sensitive biomarkers of vitamin B12 status the results indicated that low vitamin B12 was in fact significantly associated with an increased risk of cognitive decline and dementia [174]. Relatively few studies have examined the role of vitamin B6 in cognition and even fewer have examined riboflavin. Low status of vitamin B6 has been shown to contribute to cognitive dysfunction $[175,176]$ and cognitive decline [177]. Low vitamin B6 intake has been associated with a reduced risk of Alzheimer's disease [178] in older Americans. Only one study from Taiwan has investigated the role of riboflavin status and found a significant association with cognitive dysfunction, which was assessed using only a short portable mental status questionnaire and cognition was not the primary outcome [179].

Several RCTs have investigated the potential role of folate alone or in combination, with vitamins B12 and/or B6 in maintaining cognitive health in ageing, although to date most include high pharmacological doses and none include riboflavin (Table 4). One meta-analysis of nine RCTs in healthy people $(n=2835)$ concluded that folic acid had no effect on cognitive function [180]. However, in this meta-analysis, only two studies had more than 275 participants and were longer than 12 months in duration (five were $\leq 6$ months). Additionally, one recent controversial meta-analysis in almost 22,000 healthy older people concluded that neither folic acid nor vitamin B12 had a beneficial effect on "cognitive ageing" [181]. The results have been widely criticised, mainly due to the inclusion criteria used to select the trials [182-184]. Only three of the RCTs had final cognitive test scores and two thirds of the baseline results were not available. MMSE, a screening tool that is considered as a crude measure of global cognition, was the main cognitive assessment tool used. Furthermore, this meta-analysis did not identify subgroups or at risk groups in each trial that may have benefited from B-vitamins. The recent B-Vitamins for the Prevention of Osteoporotic Fractures (B-PROOF) study did show a slower rate of global cognitive decline, this was attributed to chance by the authors [185]. In general, greatest cognitive benefits have been demonstrated in RCTs involving participants with lower baseline folate status [186,187], higher homocysteine concentrations [188,189] and lower B-vitamin intake [190]. In contrast, RCTs in individuals with higher baseline folate status [191] or higher cognitive status [185] have shown no significant benefit on cognitive performance. This supports the view that baseline B-vitamin status is a critical consideration in the outcome of trials examining cognition, and further is supported by a systematic review involving $14 \mathrm{RCTs}$, which found no overall benefit of B-vitamin interventions, but reported a benefit in cognitive function in those with lower baseline folate status [192]. Thus, well designed RCTs are still required, particularly in those with sub-optimal B-vitamin status as they might benefit most in optimising B-vitamin status to maintain cognitive health in ageing. 
Table 4. Summary of Randomised Controlled Trials of 2 years or more assessing the effect of B vitamins on cognitive function in ageing.

\begin{tabular}{|c|c|c|c|c|c|c|c|}
\hline Author/Year/Trial & Country & Sample Size $(n)$ & Age (Years) & $\begin{array}{l}\text { Population Studied } \\
\text { Plasma tHcy }(\mu \mathrm{mol} / \mathrm{L})\end{array}$ & Treatment (mg/day) & Duration & Cognitive Outcomes \\
\hline \multicolumn{8}{|c|}{ Questionnaire based assessment } \\
\hline McMahon 2006 [191] & New Zealand & 276 & $\geq 65$ & $\begin{array}{l}\text { Healthy } \\
\text { tHcy }>13\end{array}$ & $1.0 \mathrm{FA}, 0.5 \mathrm{~B} 12,10 \mathrm{~B} 6$ & 2 years & No significant effect on cognition \\
\hline $\begin{array}{l}\text { FACIT } \\
\text { Durga } \\
2007[186]\end{array}$ & The Netherlands & 818 & $50-70$ & $\begin{array}{l}\text { Healthy } \\
\text { tHcy 13-26 }\end{array}$ & $0.8 \mathrm{FA}$ or placebo & 3 years & $\begin{array}{l}\text { Improvement in domains including memory, } \\
\text { information-processing and sensorimotor speed } \\
\text { No improvement in global cognition or domains of } \\
\text { complex speed or word fluency }\end{array}$ \\
\hline $\begin{array}{l}\text { WAFACS } \\
\text { Kang } \\
2008[190]\end{array}$ & USA & 2009 & $\geq 65$ & $\begin{array}{l}\text { CVD/high risk women } \\
\text { tHcy not provided }\end{array}$ & $\begin{array}{l}2.5 \mathrm{FA}, 1.0 \mathrm{~B} 12,50 \mathrm{~B} 6 \\
\text { or placebo }\end{array}$ & 6.6 years & $\begin{array}{l}\text { Reduced risk of cognitive decline among women } \\
\text { with low baseline dietary intake of B-vitamins } \\
\text { Overall no significant effect on rate of } \\
\text { cognitive decline }\end{array}$ \\
\hline $\begin{array}{l}\text { Brady } \\
2009 \text { [193] }\end{array}$ & USA & 659 & Mean 67.3 & $\begin{array}{l}\text { Advanced renal disease } \\
\text { tHcy } \geq 15\end{array}$ & $\begin{array}{l}40 \mathrm{FA}, 2.0 \mathrm{~B} 12,100 \mathrm{~B} 6 \\
\text { or placebo }\end{array}$ & 5 years & No significant effect on cognition \\
\hline $\begin{array}{l}\text { Health in Men Study: } \\
\text { sub set } \\
\text { Ford } 2010[194]\end{array}$ & Australia & 299 & $\geq 75$ & $\begin{array}{l}\text { Hypertensive men } \\
\text { Mean tHcy } 13.1-14\end{array}$ & $\begin{array}{l}2.0 \mathrm{FA}, 0.4 \mathrm{~B} 12,25 \mathrm{~B} 6 \\
\text { or placebo }\end{array}$ & 2 years & No significant effect on cognition \\
\hline $\begin{array}{l}\text { Kwok } \\
2011[189]\end{array}$ & Hong Kong & 140 & $\geq 60$ & $\begin{array}{l}\text { Dementia diagnosis } \\
\text { Mean tHcy } 14.1\end{array}$ & $\begin{array}{l}5.0 \mathrm{FA}, 1.0 \mathrm{~B} 12 \\
\text { or placebo }\end{array}$ & 2 years & $\begin{array}{l}\text { Improvement in domain of construction } \\
\text { No change in global cognitive decline, attention, } \\
\text { memory or conceptualisation }\end{array}$ \\
\hline $\begin{array}{l}\text { Beyond ageing project } \\
\text { Walker } 2012[187]\end{array}$ & Australia & 900 & $60-74$ & $\begin{array}{l}\text { Elevated psychological } \\
\text { distress } \\
\text { Mean tHcy } 9.7\end{array}$ & $\begin{array}{l}0.4 \mathrm{FA}, 0.1 \mathrm{~B} 12 \\
\text { or placebo }\end{array}$ & 2 years & $\begin{array}{l}\text { Improvement in overall global cognition and in } \\
\text { domains of immediate and delayed recall scores } \\
\text { No significant change in other cognitive domains }\end{array}$ \\
\hline $\begin{array}{l}\text { VITACOG } \\
\text { De Jager } 2012 \text { [195] }\end{array}$ & UK & 168 & $\geq 70$ & $\begin{array}{l}\text { MCI } \\
\text { Mean tHcy } 11.3\end{array}$ & $\begin{array}{l}0.8 \mathrm{FA}, 0.5 \mathrm{~B} 12,20 \mathrm{~B} 6 \\
\text { or placebo }\end{array}$ & 2 years & $\begin{array}{l}\text { Slower decline in global cognition and in domains } \\
\text { of semantic and episodic memory } \\
\text { Clinical benefit in global clinical dementia } \\
\text { rating score }\end{array}$ \\
\hline $\begin{array}{l}\text { BPROOF } \\
\text { Van Der Zwaluw } \\
2014[185]\end{array}$ & The Netherlands & 2919 & $\geq 65$ & $\begin{array}{l}\text { Healthy } \\
\text { tHcy } 12-50\end{array}$ & $\begin{array}{l}0.4 \mathrm{FA}, 0.5 \mathrm{~B} 12,0.15 \mathrm{D} 3 \\
\text { or placebo + D } 3\end{array}$ & 2 years & $\begin{array}{l}\text { Slower rate of decline in global cognition } \\
\text { No change in domains of memory }\end{array}$ \\
\hline \multicolumn{8}{|c|}{ Brain-imaging assessment } \\
\hline $\begin{array}{l}\text { VITACOG } \\
\text { Smith } 2010 \\
\text { Douaud } 2013[188,196]\end{array}$ & UK & 168 & $\geq 70$ & $\begin{array}{l}\text { MCI } \\
\text { Mean tHcy } 11.3\end{array}$ & $\begin{array}{l}0.8 \mathrm{FA}, 0.5 \mathrm{~B} 12,20 \mathrm{~B} 6 \text { or } \\
\text { placebo }\end{array}$ & 2 years & $\begin{array}{l}\text { Slowed shrinkage of brain } \\
\text { Marked reduction in cerebral atrophy in grey } \\
\text { matter regions }\end{array}$ \\
\hline $\begin{array}{l}\text { BPROOF } \\
\text { Van Der Zwaluw } \\
2014 \text { [185] }\end{array}$ & The Netherlands & 2919 & $\geq 65$ & $\begin{array}{l}\text { Healthy } \\
\text { tHcy } 12-50\end{array}$ & $\begin{array}{l}0.4 \mathrm{FA}, 0.5 \mathrm{~B} 12,0.15 \mathrm{D} 3 \\
\text { or placebo + D } 3\end{array}$ & 2 years & Awaiting MRI scan results \\
\hline
\end{tabular}

Abbreviations: tHcy, homocysteine; FA, folic acid; MMA, methylmalonic acid; holoTC, holo-transcobalamin; EPA, eicosapentaenoic; DHA, docosahexaenoic acid; MCI, mild cognitive impairment; MRI, magnetic resonance imaging; CVD, cardiovascular disease. 
Apart from evidence from observational studies and RCTs, genetic studies also provide support for the role of B-vitamins in maintaining cognitive health in ageing. The MTHFR 677TT genotype has been associated with poorer cognitive performance in Chinese males [197] and a $42 \%$ increased risk of cognitive impairment in older Australian males [198], but not in older Americans [166]. Meta-analyses have also associated the MTHFR C677T polymorphism with an increased risk of Alzheimer's disease [199], and dementia albeit in Asian populations only [200,201]. These results may be attributed to the varying prevalence of the MTHFR 677TT genotype worldwide and the modulating effect of B-vitamin status. To date, no studies have investigated interactions between this gene and B-vitamin status in relation to cognitive health.

\subsection{Future Directions}

While questionnaire based tools tests are typically used to assess cognitive performance in observational studies and RCTs, they do have inherent limitations. The use of brain imaging technology is considered a more robust measure of cognitive and brain health as it can overcome the inherent weaknesses of cognitive questionnaire based tools. MRI scans have shown that vitamin B12 status is inversely related to the rate of overall brain atrophy [202], and lower B12 status has been associated with a reduced microstructure integrity of the hippocampus [203], increased rate of brain volume losses [204,205], and a greater severity of white matter lesions [206]. Likewise, lower folate status has also been associated with severe cortical and hippocampal brain atrophy [207] and white matter lesions [161]. Furthermore, the VITACOG trial demonstrated that combined folate, B12 and B6 supplementation over two years markedly reduced (by up to 53\%) the rate of brain atrophy. This effect was modulated by baseline homocysteine concentration, with the greatest impact observed in those with concentrations $\geq 13 \mu \mathrm{mol} / \mathrm{L}$ [196]. A reduction in cerebral atrophy by as much as seven fold was also observed in grey matter regions, which are the most relevant regions for Alzheimer's disease pathology [188]. More recently, the use of a new functional neuroimaging technique, magnetoencephalography (MEG), has emerged which can map brain activity and assess cognitive processes and specific functions of the brain [208]. MEG is currently being used in some clinical studies, including cognitive studies in ageing, but to date none have examined B-vitamins. Brain imaging could therefore help further elucidate the role and underlying mechanism linking B-vitamins with brain health and disease.

Future studies are therefore warranted to investigate the effects (and interactions) of folate, the related B-vitamins, and relevant genetic variants, particularly in cohorts with lower B-vitamin status. Longitudinal studies are also required to explore differential effects on cognition over time. Targeted RCTs of sufficient duration, with lower doses of B-vitamins at levels achievable through dietary means, are also indicated.

\section{Potential Mechanisms Linking B-Vitamins with Diseases of Ageing}

Although no clear mechanisms have been established, a variety of biologically plausible mechanisms have been suggested to explain the role of B-vitamins in the diseases of ageing $[85,156]$. In the brain and other tissues, folate and the metabolically related B-vitamins are required as co-factors for one-carbon transfer reactions, which in turn are fundamental for the synthesis of DNA and RNA nucleotides, the metabolism of amino acids and the maintenance of methylation reactions [6,7]. Thus, the proposed mechanisms by which sub-optimal B-vitamins status or deficiency could contribute to greater risk of cognitive impairment and other diseases of ageing, involve perturbations in the complex regulatory network maintaining one-carbon metabolism [11,12]. This can result in hyperhomocysteinemia [209] and/or reduced methylation status within the relevant tissue [210,211], increased misincorporation of uracil into DNA, and altered RNA [212-214] and neurotransmitter products [215]. Vitamin B6 is important in brain health as pyridoxine is a co-factor in transamination and decarboxylation reactions required for the metabolism of several neurotransmitters, including serotonin, dopamine, and histamine [216]. Elevated homocysteine and/or lower B-vitamins can 
also impact on the immune system and cause increased inflammation and antioxidant damage, alone or in synergy, which can have adverse effects on the disease of ageing through the vascular system and atherosclerosis [217-219]. B-vitamins have also been shown to have an indirect role on bone remodelling and protective effects on bone formation which help to maintain bone health in ageing [220-222]. Cognitive deficits and Alzheimer's disease has also been observed in B-vitamin deficient rats and been attributed to abnormal methylation [223,224].

Specific genetic polymorphisms, including the common MTHFR $677 \mathrm{C} \rightarrow \mathrm{T}$ polymorphism can disrupt normal one-carbon metabolism and thus have an impact on diseases of ageing, independent of homocysteine, as a result of impairments in methylation activity; improved B-vitamin status could help to modulate this risk $[13,225,226]$. Furthermore, this polymorphism has more recently been associated with blood pressure while riboflavin has emerged as having a novel role in lowering blood pressure in hypertensive patients with the variant MTHFR 677TT genotype [110]. The effect of the MTHFR $677 \mathrm{C} \rightarrow \mathrm{T}$ polymorphism on blood pressure might be mediated by nitric oxide, a potent vasodilator, and riboflavin has been demonstrated as a means to restoring MTHFR activity in vivo [58]. The interaction between the MTHFR genotype, B-vitamin status and risk of hypertension requires further exploration.

\section{Public Health Implications}

Folic acid food fortification was instigated primarily to reduce the prevalence of neural tube defects (NTDs) but it may also have additional benefits for the ageing population. Currently, 80 countries have mandatory folic acid food fortification policies in place, including America and Canada [227]. As a result of fortification, there has been a dramatic fall in NTDs [228] and folate deficiency in the USA and Canada is practically non-existent [34,36,229]. Mandatory folic acid food fortification has also lead to an improvement in stroke mortality in the US and Canada [98] and could have additional beneficial effects in maintaining better cognitive function [230] and bone health [231] in older people. No European country has a mandatory folic acid food fortification policy but most do allow voluntary food fortification. The UK and Ireland have quite liberal voluntary fortification polices and are currently considering mandatory fortification. Voluntary food fortification has resulted in significantly higher dietary intakes and biomarker status of folate and related B-vitamins in Irish adults of all ages $[232,233]$. The NANS dietary survey however highlighted that the overall $21 \%$ of Irish adults who were non-consumers of fortified foods were at higher risk of sub-optimal status of folate and related B-vitamins [233]. Regular fortified food consumption therefore has the potential to improve dietary and biomarker status of B-vitamins but a mandatory food fortification would ensure that the whole population were protected.

Low vitamin B12 status in older people is also a concern. Current dietary recommendations for vitamin B12 range between $2.4 \mu \mathrm{g} /$ day in the USA [234] and $4 \mu \mathrm{g} /$ day in Europe [235]. However, the European recommendations do not account for the high prevalence of food-bound malabsorption in older people, whereas people aged $\geq 50$ years in the USA are recommended to consume most of their vitamin B12 from crystalline sources (i.e., fortified food and supplements) in order to overcome food-bound B12 malabsorption [234]. The synthetic form of vitamin B12, found in fortified foods and supplements, is freely available and thus has no gastric acid requirement [40]. Furthermore, there was a previous safety concern that the high folic acid intake may potentially mask the anaemia of vitamin B12 deficiency and thus delay diagnosis resulting in irreversible nerve damage $[79,236]$. Mandatory food fortification in the USA however has not led to these adverse events [237-239]. Therefore, from a public health perspective, there are significant challenges in relation to maintaining vitamin B12 in older people and vitamin B12 food fortification could help address some of these challenges.

Concerns have been raised as regards a possible adverse interaction of high folate with low vitamin B12 leading to an increased risk of cognitive impairment in the USA and Australia [230,240,241], but this is rather controversial. Two studies in the UK and USA failed to detect such an adverse interaction $[238,242]$ and one study in the Netherlands in fact found that this combination (i.e., high 
folate and low B12) was associated with a reduced risk of cognitive impairment [243]. Discrepancies among studies in this regard may in part be attributed to the relatively low numbers in most studies with this folate/vitamin B12 combination and the type of biomarker used or the cut off value used to define low status in each study. Additionally, a recent US review concluded that the current observational data was limited and that no RCTs had investigated this folate-B12 interaction in cognitive health [244]. Concerns have also been raised that excessively high folate intakes could have cancer promoting effects in segments of the ageing population [245-247]. A Scientific Advisory Committee on Nutrition (SACN) review in the UK however found insufficient evidence to support the view that mandatory folic acid fortification would promote cancer [248]. Excessive folic acid intakes have also been reported to increase un-metabolized folic acid in the circulation with potential adverse effects on health [34,249], although a recent international review did not find any health concerns even at very high folic acid levels [20]. Suggestions have been made to include both folic acid and vitamin B12 in mandatory food fortification policies, to prevent adverse health outcomes and address food-bound malabsorption but the costs of such an approach may be prohibitive. Furthermore, vitamin B6 and riboflavin status in older people is also of concern and may be much more important than previously appreciated for public health in ageing. Therefore, those contemplating public health issues worldwide need to consider a balanced approach and should endeavour to achieve optimal status of all relevant B-vitamins throughout all stages of life.

\section{Conclusions}

In summary, folate and the metabolically related B-vitamins, B12, B6 and riboflavin, have a vital role in maintaining one-carbon metabolism and any perturbation in this pathway as a result of low/deficient B-vitamin status can impact on health through a number of related mechanisms. Evidence is accumulating to support the beneficial role of B-vitamins in maintaining cardiovascular, bone and brain health in ageing, with the most at risk sub-populations benefiting from optimising one/more B-vitamins involved in one-carbon metabolism. To date, studies investigating the role of B-vitamins in health and disease have tended to focus predominantly on folate and vitamin B12. Future well designed research is warranted to further investigate the metabolically linked B-vitamins B6 and riboflavin, and should include robust and sensitive measures of B-vitamins as well as novel measures of the health outcome of interest (e.g., imaging techniques to assess brain function). In an era where personalised nutrition has gained much attention, further work is also needed to explore the role of the interaction of the MTHFR $677 \mathrm{C} \rightarrow \mathrm{T}$ polymorphism with both folate and riboflavin, given that this gene-nutrient interaction has the potential to modulate the risk of disease.

Acknowledgments: K.P.'s Ph.D. studentship was funded by the Northern Ireland Department for Employment and Learning who had no role in the design, analysis or writing of this paper.

Author Contributions: K.P. drafted the manuscript. H.M., L.H., C.F.H. and M.W. critically revised the manuscript for important intellectual content. All the authors have read and approved the final manuscript.

Conflicts of Interest: The authors declare no conflict of interest.

\section{References}

1. Beard, J.R.; Bloom, D.E. Towards a comprehensive public health response to population ageing. Lancet 2015, 385, 658-661. [CrossRef]

2. Prince, M.; Wu, F.; Guo, Y.; Gutierrez Robledo, L.; O'Donnell, M.; Sullivan, R.; Yusuf, S. The burden of disease in older people and implications for health policy and practice. Lancet 2015, 385, 549-562. [CrossRef]

3. A Global Brief on Hypertension. Available online: http://ish-world.com/news/a/World-HealthOrganization-A-Global-Brief-on-Hypertension/ (accessed on 1 August 2016).

4. Johnell, O.; Kanis, J.A. An estimate of the worldwide prevalence and disability associated with osteoporotic fractures. Osteoporos. Int. 2006, 17, 1726-1733. [CrossRef] [PubMed]

5. Prince, M.; Wimo, A.; Guerchet, M.; Ali, G.C.; Wu, Y.-T.; Prina, M.; International, A.D. World Alzheimer's Report-The Global Impact of Dementia; Alzheimer's Disease International: London, UK, 2015. 
6. Selhub, J. Folate, vitamin B12 and vitamin B6 and one carbon metabolism. J. Nutr. Health Aging 2002, 6, 39-42. [PubMed]

7. Kennedy, D.O. B Vitamins and the Brain: Mechanisms, Dose and Efficacy-A Review. Nutrients 2016, 8, 68. [CrossRef] [PubMed]

8. McGarel, C.; Pentieva, K.; Strain, J.J.; McNulty, H. Emerging roles for folate and related B-vitamins in brain health across the lifecycle. Proc. Nutr. Soc. 2015, 74, 46-55. [CrossRef] [PubMed]

9. Molloy, A. Folate-vitamin B12 interrelationships; links to disease risk. In Folate in Health and Disease, 2nd ed.; Bailey, L., Ed.; CRC Press: Boca Raton, FL, USA, 2010; pp. 381-408.

10. Scott, J.; Weir, D. The methyl folate trap: A physiological response in man to prevent methyl group deficiency in kwashiorkor (methionine deficiency) and an explanation for folic-acid-induced exacerbation of subacute combined degeneration in pernicious anaemia. Lancet 1981, 318, 337-340. [CrossRef]

11. Brachet, P.; Chanson, A.; Demigne, C.; Batifoulier, F.; Alexandre-Gouabau, M.C.; Tyssandier, V.; Rock, E. Age-associated B vitamin deficiency as a determinant of chronic diseases. Nutr. Res. Rev. 2004, 17, 55-68. [CrossRef] [PubMed]

12. Araujo, J.R.; Martel, F.; Borges, N.; Araujo, J.M.; Keating, E. Folates and aging: Role in mild cognitive impairment, dementia and depression. Ageing Res. Rev. 2015, 22, 9-19. [CrossRef] [PubMed]

13. Lai, C.; Parnell, L.D.; Troen, A.M.; Shen, J.; Caouette, H.; Warodomwichit, D.; Lee, Y.; Crott, J.W.; Qiu, W.Q.; Rosenberg, I.H.; et al. MAT1A variants are associated with hypertension, stroke, and markers of DNA damage and are modulated by plasma vitamin B-6 and folate. Am. J. Clin. Nutr. 2010, 91, 1377-1386. [CrossRef] [PubMed]

14. Wilcken, B.; Bamforth, F.; Li, Z.; Zhu, H.; Ritvanen, A.; Redlund, M.; Stoll, C.; Alembik, Y.; Dott, B.; Czeizel, A.E.; et al. Geographical and ethnic variation of the $677 \mathrm{C}>\mathrm{T}$ allele of 5,10-methylenetetrahydrofolate reductase (MTHFR): Findings from over 7000 newborns from 16 areas Worldwide. J. Med. Genet. 2003, 40, 619-625. [CrossRef] [PubMed]

15. Reilly, R.; Hopkins, S.; Ward, M.; McNulty, H.; McCann, A.; McNulty, B.; Walton, J.; Molloy, A.; Strain, J.J.; Flynn, A.; et al. MTHFR 677TT genotype and related B-vitamins: Novel determinants of hypertension in healthy Irish adults. J. Inherit. Metab. Dis. 2013, 36, 35.

16. Clarke, M.; Ward, M.; Dickey, W.; Hoey, L.; Molloy, A.M.; Waldron, L.; Varghese, A.; McCann, A.; Blayney, J.K.; McNulty, H. B-vitamin status in relation to bone mineral density in treated celiac disease patients. Scand. J. Gastroenterol. 2015, 50, 975-984. [CrossRef] [PubMed]

17. Ter Borg, S.; Verlaan, S.; Hemsworth, J.; Mijnarends, D.M.; Schols, J.M.G.A.; Luiking, Y.C.; De Groot, L.C.P.G.M. Micronutrient intakes and potential inadequacies of community-dwelling older adults: A systematic review. Br. J. Nutr. 2015, 113, 1195-1206. [CrossRef] [PubMed]

18. Bates, B.; Lennox, A.; Bates, C. National Diet and Nutrition Survey: Results from Years 1-4 (Combined) of the Rolling Programme (2008/2009-2011/12); Public Health England: London, UK, 2014.

19. Lindenbaum, J.; Allen, R. Clinical spectrum and diagnosis of folate deficiency. In Folate in Health and Disease, 2nd ed.; Bailey, L., Ed.; CRC Press: London, UK, 2009; pp. 43-67.

20. Bailey, L.B.; Stover, P.J.; McNulty, H.; Fenech, M.F.; Gregory, J.F., III; Mills, J.L.; Pfeiffer, C.M.; Fazili, Z.; Zhang, M.; Ueland, P.M.; et al. Biomarkers of Nutrition for Development-Folate Review. J. Nutr. 2015, 145, 1636-1680. [CrossRef] [PubMed]

21. Gibson, R. Assessment status of riboflavin, B6, folate and B12 status. In Principles of Nutritional Assessment, 2nd ed.; Oxford University: New York, NY, USA, 2005; pp. 554-562, 575-640.

22. Carmel, R.; Jacobsen, D. (Eds.) Homocysteine in Health and Disease; Cambridge University Press: Cambridge, UK, 2001.

23. Selhub, J.; Jacques, P.F.; Bostom, A.G.; Wilson, P.W.; Rosenberg, I.H. Relationship between plasma homocysteine and vitamin status in the Framingham study population. Impact of folic acid fortification. Public Health Rev. 2000, 28, 117-145. [PubMed]

24. McKillop, D.; Pentieva, K.; Daly, D.; McPartlin, J.; Hughes, J.; Strain, J.; Scott, J.; McNulty, H. The effect of different cooking methods on folate retention in various foods that are amongst the major contributors to folate intake in the UK diet. Br. J. Nutr. 2002, 88, 681-688. [CrossRef] [PubMed]

25. McNulty, H.; Scott, J.M. Intake and status of folate and related B-vitamins: Considerations and challenges in achieving optimal status. Br. J. Nutr. 2008, 99, S48-S54. [CrossRef] [PubMed] 
26. Selhub, J.; Bagley, L.C.; Miller, J.; Rosenberg, I.H. B vitamins, homocysteine, and neurocognitive function in the elderly. Am. J. Clin. Nutr. 2000, 71, 614S-620S. [PubMed]

27. Powers, H.J. Riboflavin (vitamin B-2) and health. Am. J. Clin. Nutr. 2003, 77, 1352-1360. [PubMed]

28. Allen, L.H. How common is vitamin B-12 deficiency? Am. J. Clin. Nutr. 2009, 89, 693S-696S. [CrossRef] [PubMed]

29. Refsum, H.; Yajnik, C.S.; Gadkari, M.; Schneede, J.; Vollset, S.E.; Orning, L.; Guttormsen, A.B.; Joglekar, A.; Sayyad, M.G.; Ulvik, A.; et al. Hyperhomocysteinemia and elevated methylmalonic acid indicate a high prevalence of cobalamin deficiency in Asian Indians. Am. J. Clin. Nutr. 2001, 74, 233-241. [PubMed]

30. Antony, A.C. Prevalence of cobalamin (vitamin B-12) and folate deficiency in India-Audi alteram partem. Am. J. Clin. Nutr. 2001, 74, 233-241.

31. Clarke, R.; Refsum, H.; Birks, J.; Evans, J.G.; Johnston, C.; Sherliker, P.; Ueland, P.M.; Schneede, J.; McPartlin, J.; Nexo, E.; et al. Screening for vitamin B-12 and folate deficiency in older persons. Am. J. Clin. Nutr. 2003, 77, 1241-1247. [PubMed]

32. Clarke, R.; Sherliker, P.; Hin, H.; Nexo, E.; Hvas, A.M.; Schneede, J.; Birks, J.; Ueland, P.M.; Emmens, K.; Scott, J.M.; et al. Detection of vitamin B-12 deficiency in older people by measuring vitamin B-12 or the active fraction of vitamin B-12, holotranscobalamin. Clin. Chem. 2007, 53, 963-970. [CrossRef] [PubMed]

33. Clarke, R.; Grimley Evans, J.; Schneede, J.; Nexo, E.; Bates, C.; Fletcher, A.; Prentice, A.; Johnston, C.; Ueland, P.M.; Refsum, H.; et al. Vitamin B12 and folate deficiency in later life. Age Ageing 2004, 33, $34-41$. [CrossRef] [PubMed]

34. Pfeiffer, C.M.; Caudill, S.P.; Gunter, E.W.; Osterloh, J.; Sampson, E.J. Biochemical indicators of B vitamin status in the US population after folic acid fortification: Results from the National Health and Nutrition Examination Survey 1999-2000. Am. J. Clin. Nutr. 2005, 82, 442-450. [PubMed]

35. Pfeiffer, C.M.; Johnson, C.L.; Jain, R.B.; Yetley, E.A.; Picciano, M.F.; Rader, J.I.; Fisher, K.D.; Mulinare, J.; Osterloh, J.D. Trends in blood folate and vitamin B-12 concentrations in the United States, 1988-2004. Am. J. Clin. Nutr. 2007, 86, 718-727. [PubMed]

36. MacFarlane, A.J.; Greene-Finestone, L.S.; Shi, Y. Vitamin B-12 and homocysteine status in a folate-replete population: Results from the Canadian Health Measures Survey. Am. J. Clin. Nutr. 2011, 94, 1079-1087. [CrossRef] [PubMed]

37. Green, T.J.; Venn, B.J.; Skeaff, C.M.; Williams, S.M. Serum vitamin B-12 concentrations and atrophic gastritis in older New Zealanders. Eur. J. Clin. Nutr. 2005, 59, 205-210. [CrossRef] [PubMed]

38. Loikas, S.; Koskinen, P.; Irjala, K.; Lopponen, M.; Isoaho, R.; Kivela, S.; Pelliniemi, T. Vitamin B12 deficiency in the aged: A population-based study. Age Ageing 2007, 36, 177-183. [CrossRef] [PubMed]

39. Carmel, R. Cobalamin, the stomach, and aging. Am. J. Clin. Nutr. 1997, 66, 750-759. [PubMed]

40. Hughes, C.F.; Ward, M.; Hoey, L.; McNulty, H. Vitamin B-12 and ageing: Current issues and interaction with folate. Ann. Clin. Biochem. 2013, 50, 315-329. [CrossRef] [PubMed]

41. Van Asselt, D.Z.B.; De Groot, L.C.P.G.M.; Van Staveren, W.A.; Blom, H.J.; Wevers, R.A.; Biemond, I.; Hoefnagels, W.H.L. Role of cobalamin intake and atrophic gastritis in mild cobalamin deficiency in older Dutch subjects. Am. J. Clin. Nutr. 1998, 68, 328-334. [PubMed]

42. Hannibal, L.; Lysne, V.; Bjørke-Monsen, A.L.; Behringer, S.; Grünert, S.C.; Spiekerkoetter, U.; Jacobsen, D.W.; Blom, H.J. Biomarkers and algorithms for the diagnosis of vitamin B12 deficiency. Front. Mol. Biosci. 2016, 3, 27. [CrossRef] [PubMed]

43. Valuck, R.J.; Ruscin, J.M. A case-control study on adverse effects: H2 blocker or proton pump inhibitor use and risk of vitamin B-12 deficiency in older adults. J. Clin. Epidemiol. 2004, 57, 422-428. [CrossRef] [PubMed]

44. Masclee, G.M.C.; Sturkenboom, M.C.J.M.; Kuipers, E.J. A Benefit-Risk Assessment of the Use of Proton Pump Inhibitors in the Elderly. Drugs Aging 2014, 31, 263-282. [CrossRef] [PubMed]

45. Lam, J.R.; Schneider, J.L.; Zhao, W.; Corley, D.A. Proton pump inhibitor and histamine 2 receptor antagonist use and vitamin B-12 deficiency. JAMA 2013, 310, 2435-2442. [CrossRef] [PubMed]

46. Chapman, L.E.; Darling, A.L.; Brown, J.E. Association between metformin and vitamin B12 deficiency in patients with type 2 diabetes: A systematic review and meta-analysis. Diabetes Metab. 2016. [CrossRef] [PubMed] 
47. Aroda, V.R.; Edelstein, S.L.; Goldberg, R.B.; Knowler, W.C.; Marcovina, S.M.; Orchard, T.J.; Bray, G.A.; Schade, D.S.; Temprosa, M.G.; White, N.H.; et al. Long-term metformin use and vitamin B12 deficiency in the diabetes prevention program outcomes study. J. Clin. Endocrinol. Metab. 2016, 101, 1754-1761. [CrossRef] [PubMed]

48. Haller, J. The vitamin status and its adequacy in the elderly: An international overview. Int. J. Vitam. Nutr. Res. 1999, 69, 160-168. [CrossRef] [PubMed]

49. Bates, C.; Pentieva, K.; Prentice, A.; Mansoor, M.; Finch, S. Plasma pyridoxal phosphate and pyridoxic acid and their relationship to plasma homocysteine in a representative sample of British men and women aged 65 years and over. Br. J. Nutr. 1999, 81, 191-201. [PubMed]

50. Morris, M.S.; Picciano, M.F.; Jacques, P.F.; Selhub, J. Plasma pyridoxal 5'-phosphate in the US population: The National Health and Nutrition Examination Survey, 2003-2004. Am. J. Clin. Nutr. 2008, 87, 1446-1454. [PubMed]

51. Ribayamercado, J.; Russell, R.; Sahyoun, N.; Morrow, F.; Gershoff, S. Vitamin-B6 requirements of elderly men and women. J. Nutr. 1991, 121, 1062-1074.

52. Van Den Berg, H. Vitamin B6 status and requirements in older adults. Br. J. Nutr. 1999, 81, 175-176. [PubMed]

53. Troesch, B.; Hoeft, B.; McBurney, M.; Eggersdorfer, M.; Weber, P. Dietary surveys indicate vitamin intakes below recommendations are common in representative Western countries. Br. J. Nutr. 2012, 108, 692-698. [CrossRef] [PubMed]

54. Bates, B.; Cox, L.; Page, S.; Prentice, A.; Steer, T.; Swan, G. National Diet and Nutrition Survey: Results from Years 5 and 6 (Combined) of the Rolling Programme (2012/2013-2013/2014); Public Health England: London, UK, 2016.

55. Walton, J.; Flynn, A. NANS: Food and Nutrient Intakes, Physical Measurements, Physical Activity Patterns and Food Choice Motives; Irish Universities Nutrition Alliance: Dublin, Ireland, 2011; pp. 1-40.

56. Eussen, S.J.P.M.; De Groot, C.P.G.M.; Clarke, R.; Schneede, J.; Ueland, P.M.; Hoefnagels, W.H.L.; Van Staveren, W.A. Oral cyanocobalamin supplementation in older people with vitamin B-12 deficiency-A dose-finding trial. Arch. Intern. Med. 2005, 165, 1167-1172. [CrossRef] [PubMed]

57. McKinley, M.C.; McNulty, H.; McPartlin, J.; Strain, J.J.; Pentieva, K.; Ward, M.; Weir, D.G.; Scott, J.M. Low-dose vitamin B-6 effectively lowers fasting plasma homocysteine in healthy elderly persons who are folate and riboflavin replete. Am. J. Clin. Nutr. 2001, 73, 759-764. [PubMed]

58. McNulty, H.; Dowey, L.R.C.; Strain, J.J.; Dunne, A.; Ward, M.; Molloy, A.M.; McAnena, L.B.; Hughes, J.P.; Hannon-Fletcher, M.; Scott, J.M. Riboflavin lowers homocysteine in individuals homozygous for the MTHFR 677C $\rightarrow$ T polymorphism. Circulation 2006, 113, 74-80. [CrossRef] [PubMed]

59. Pfeiffer, C.; Fazili, Z.; Zhang, M. Folate analytical methodology. In Folate in Health and Disease, 2nd ed.; Bailey, L.B., Ed.; CRC Press: Boca Raton, FL, USA, 2010; pp. 517-574.

60. Mason, J.B. Biomarkers of nutrient exposure and status in one-carbon (methyl) metabolism. J. Nutr. 2003, 133, 941S-947S. [PubMed]

61. Clifford, A.J.; Noceti, E.M.; Block-Joy, A.; Block, T.; Block, G. Erythrocyte folate and its response to folic acid supplementation is assay dependent in women. J. Nutr. 2005, 135, 137-143. [PubMed]

62. Wu, A.; Chanarin, I.; Slavin, G.; Levi, A.J. Folate-Deficiency in alcoholic-Relationship to clinical and hematological abnormalities, liver-disease and folate stores. Br. J. Haematol. 1975, 29, 469-478. [CrossRef] [PubMed]

63. Duffy, M.E.; Hoey, L.; Hughes, C.F.; Strain, J.J.; Rankin, A.; Souverein, O.W.; Dullemeijer, C.; Collings, R.; Hooper, L.; McNulty, H. Biomarker responses to folic acid intervention in healthy adults: A meta-analysis of randomized controlled trials. Am. J. Clin. Nutr. 2014, 99, 96-106. [CrossRef] [PubMed]

64. Carmel, R. Current concepts in cobalamin deficiency. Annu. Rev. Med. 2000, 51, 357-375. [CrossRef] [PubMed]

65. Lindenbaum, J.; Rosenberg, I.H.; Wilson, P.W.F.; Stabler, S.P.; Allen, R.H. Prevalence of cobalamin deficiency in the Framingham elderly population. Am. J. Clin. Nutr. 1994, 60, 2-11. [PubMed]

66. Naurath, H.J.; Joosten, E.; Riezler, R.; Stabler, S.P.; Allen, R.H.; Lindenbaum, J. Effects of vitamin-B12, folate, and vitamin-B6 supplements in elderly people with normal serum vitamin concentrations. Lancet 1995, 346, 85-89. [CrossRef] 
67. Carmel, R.; Green, R.; Jacobsen, D.W.; Rasmussen, K.; Florea, M.; Azen, C. Serum cobalamin, homocysteine, and methylmalonic acid concentrations in a multiethnic elderly population: Ethnic and sex differences in cobalamin and metabolite abnormalities. Am. J. Clin. Nutr. 1999, 70, 904-910. [PubMed]

68. Riedel, B.M.; Molloy, A.M.; Meyer, K.; Fredriksen, A.; Ulvik, A.; Schneede, J.; Nexo, E.; Hoff, G.; Ueland, P.M. Transcobalamin Polymorphism 67A $\rightarrow$ G, but Not 776C $\rightarrow$ G, Affects serum holotranscobalamin in a cohort of healthy middle-aged men and women. J. Nutr. 2011, 141, 1784-1790. [CrossRef] [PubMed]

69. Iqbal, N.; Azar, D.; Yun, Y.; Ghausi, O.; Ix, J.; Fitzgerald, R.L. Serum methylmalonic Acid and holotranscobalamin-II as markers for vitamin b12 deficiency in end-stage renal disease patients. Ann. Clin. Lab. Sci. 2013, 43, 243-249. [PubMed]

70. Carmel, R. Biomarkers of cobalamin (vitamin B-12) status in the epidemiologic setting: A critical overview of context, applications, and performance characteristics of cobalamin, methylmalonic acid, and holotranscobalamin II. Am. J. Clin. Nutr. 2011, 94, 348S-358S. [CrossRef] [PubMed]

71. Leklem, J.E. Vitamin-B6-A status-report. J. Nutr. 1990, 120, 1503-1507. [PubMed]

72. Ueland, P.M.; Ulvik, A.; Rios-Avila, L.; Midttun, O.; Gregory, J.F. Direct and functional biomarkers of vitamin b6 status. Annu. Rev. Nutr. 2015, 35, 33-70. [CrossRef] [PubMed]

73. Chiang, E.P.; Smith, D.E.; Selhub, J.; Dallal, G.; Wang, Y.C.; Roubenoff, R. Inflammation causes tissue-specific depletion of vitamin B-6. Arthritis Res. Ther. 2005, 7, R1254-R1262. [CrossRef] [PubMed]

74. Hoey, L.; McNulty, H.; Strain, J.J. Studies of biomarker responses to intervention with riboflavin: A systematic review. Am. J. Clin. Nutr. 2009, 89, 1960S-1980S. [CrossRef] [PubMed]

75. Yetley, E.A.; Johnson, C.L. Folate and vitamin B-12 biomarkers in NHANES: History of their measurement and use. Am. J. Clin. Nutr. 2011, 94, 322S-331S. [CrossRef] [PubMed]

76. Hoey, L.; Strain, J.J.; McNulty, H. Studies of biomarker responses to intervention with vitamin B-12: A systematic review of randomized controlled trials. Am. J. Clin. Nutr. 2009, 89, 1981S-1996S. [CrossRef] [PubMed]

77. Bisp, M.R.; Bor, M.V.; Heinsvig, E.M.; Kall, M.A.; Nexo, E. Determination of vitamin B6 vitamers and pyridoxic acid in plasma: Development and evaluation of a high-performance liquid chromatographic assay. Anal. Biochem. 2002, 305, 82-89. [CrossRef] [PubMed]

78. Apeland, T.; Mansoor, M.A.; Pentieva, K.; McNulty, H.; Strandjord, R.E. Fasting and post-methionine loading concentrations of homocysteine, vitamin B2, and vitamin B6 in patients on antiepileptic drugs. Clin. Chem. 2003, 49, 1005-1008. [CrossRef] [PubMed]

79. Reynolds, E. Vitamin B12, folic acid, and the nervous system. Lancet Neurol. 2006, 5, 949-960. [CrossRef]

80. Scott, J.; Weir, D. Folate/vitamin B12 inter-relationships. Essays Biochem. 1994, 28, 63-72. [PubMed]

81. Healton, E.; Brust, J.; Garrett, T.; Lindenbaum, J. Neurologic aspects of coabalmin deficiency. Medicine 1991, 70, 229-245. [CrossRef] [PubMed]

82. Rampersaud, G.C.; Kauwell, G.P.A.; Bailey, L.B. Folate: A key to optimizing health and reducing disease risk in the elderly. J. Am. Coll. Nutr. 2003, 22, 1-8. [CrossRef] [PubMed]

83. Homocysteine Studies Collaboration. Homocysteine and risk of ischemic heart disease and stroke: A meta-analysis. JAMA 2002, 288, 2015-2022.

84. Wald, D.S.; Law, M.; Morris, J.K. Homocysteine and cardiovascular disease: Evidence on causality from a meta-analysis. Br. Med. J. 2002, 325, 1202K-1206K. [CrossRef]

85. Smith, D.A.; Refsum, H. Homocysteine, B Vitamins, and Cognitive Impairment. Annu. Rev. Nutr. 2016, 36, 211-239. [CrossRef] [PubMed]

86. Wald, D.S.; Morris, J.K.; Wald, N.J. Reconciling the Evidence on Serum Homocysteine and Ischaemic Heart Disease: A Meta-Analysis. PLoS ONE 2011, 6, e16473. [CrossRef] [PubMed]

87. Wald, D.S.; Kasturiratne, A.; Simmonds, M. Serum homocysteine and dementia: Meta-analysis of eight cohort studies including 8669 participants. Alzheimer's Dement. 2011, 7, 412-417. [CrossRef] [PubMed]

88. Yang, H.; Lee, M.; Hong, K.; Ovbiagele, B.; Saver, J.L. Efficacy of folic acid supplementation in cardiovascular disease prevention: An updated meta-analysis of randomized controlled trials. Eur. J. Intern. Med. 2012, 23, 745-754. [CrossRef] [PubMed]

89. Enneman, A.W.; Swart, K.M.; Van Wijngaarden, J.P.; Zillikens, M.C.; Dhonukshe-Rutten, R.A.; De Groot, L.C.; Van Schoor, N.M.; Lips, P.; Van Meurs, J.B.; Uitterlinden, A.G.; et al. Association between plasma homocysteine and bone density and quality parameters in the elderly. Bone 2012, 50, S134. [CrossRef] 
90. McNulty, H.; Strain, J.J.; Pentieva, K.; Ward, M. C-1 metabolism and CVD outcomes in older adults. Proc. Nutr. Soc. 2012, 71, 213-221. [CrossRef] [PubMed]

91. Toole, J.F.; Malinow, M.R.; Chambless, L.E.; Spence, J.D.; Pettigrew, L.C.; Howard, V.J.; Sides, E.G.; Wang, C.; Stampfer, M. Lowering homocysteine in patients with ischemic stroke to prevent recurrent stroke, myocardial infarction, and death: The Vitamin Intervention for Stroke Prevention (VISP) randomized controlled trial. JAMA 2004, 291, 565-575. [CrossRef] [PubMed]

92. Bonaa, K.H.; Njolstad, I.; Ueland, P.M.; Schirmer, H.; Tverdal, A.; Steigen, T.; Wang, H.; Nordrehaug, J.E.; Arnesen, E.; Rasmussen, K. Homocysteine lowering and cardiovascular events after acute myocardial infarction. N. Engl. J. Med. 2006, 354, 1578-1588. [CrossRef] [PubMed]

93. Lonn, E.; Yusuf, S.; Arnold, M.J.; Sheridan, P.; Pogue, J.; Micks, M.; McQueen, M.J.; Probstfield, J.; Fodor, G.; Held, C.; et al. Homocysteine lowering with folic acid and B vitamins in vascular disease. N. Engl. J. Med. 2006, 354, 1567-1577. [PubMed]

94. Albert, C.M.; Cook, N.R.; Gaziano, J.M.; Zaharris, E.; MacFadyen, J.; Danielson, E.; Buring, J.E.; Manson, J.E. Effect of folic acid and B vitamins on risk of cardiovascular events and total mortality among women at high risk for cardiovascular disease: A randomized trial. JAMA 2008, 299, 2027-2036. [CrossRef] [PubMed]

95. Ebbing, M.; Bleie, O.; Ueland, P.M.; Nordrehaug, J.E.; Nilsen, D.W.; Vollset, S.E.; Refsum, H.; Pedersen, E.K.R.; Nygard, O. Mortality and cardiovascular events in patients treated with homocysteine-lowering B vitamins after coronary angiography-A Randomized controlled trial. JAMA 2008, 300, 795-804. [CrossRef] [PubMed]

96. Hankey, G.J.; Eikelboom, J.W.; Baker, R.I.; Gelavis, A.; Hickling, S.C.; Jamrozik, K.; Van Bockxmeer, F.M.; Vasikaran, S.; Hankey, G.J.; Chen, C.; et al. B vitamins in patients with recent transient ischaemic attack or stroke in the VITAmins TO Prevent Stroke (VITATOPS) trial: A randomised, double-blind, parallel, placebo-controlled trial. Lancet Neurol. 2010, 9, 855-865.

97. Clarke, R.; Bennett, D.A.; Parish, S.; Verhoef, P.; Dotsch-Klerk, M.; Lathrop, M.; Xu, P.; Nordestgaard, B.G.; Holm, H.; Hopewell, J.C.; et al. Homocysteine and Coronary Heart Disease: Meta-analysis of MTHFR Case-Control Studies, Avoiding Publication Bias. PLoS Med. 2012, 9, e1001177. [CrossRef] [PubMed]

98. Yang, Q.H.; Botto, L.D.; Erickson, J.D.; Berry, R.J.; Sambell, C.; Johansen, H.; Friedman, J.M. Improvement in stroke mortality in Canada and the United States, 1990 to 2002. Circulation 2006, 113, 1335-1343. [CrossRef] [PubMed]

99. Wang, X.; Qin, X.; Demirtas, H.; Li, J.; Mao, G.; Huo, Y.; Sun, N.; Liu, L.; Xu, X. Efficacy of folic acid supplementation in stroke prevention: A meta-analysis. Lancet 2007, 369, 1876-1882. [CrossRef]

100. Lee, M.; Hong, K.; Chang, S.; Saver, J.L. Efficacy of homocysteine-lowering therapy with folic acid in stroke prevention: A meta-analysis. Stroke 2010, 41, 1205-1212. [CrossRef] [PubMed]

101. Huo, Y.; Li, J.; Qin, X.; Huang, Y.; Wang, X.; Gottesman, R.F.; Tang, G.; Wang, B.; Chen, D.; He, M.; et al. Efficacy of folic acid therapy in primary prevention of stroke among adults with hypertension in China the CSPPT Randomized Clinical Trial. JAMA 2015, 313, 1325-1335. [CrossRef] [PubMed]

102. Li, Y.; Huang, T.; Zheng, Y.; Muka, T.; Troup, J.; Hu, F.B. Folic acid supplementation and the risk of cardiovascular diseases: A meta-Analysis of randomized controlled trials. J. Am. Heart Assoc. 2016, 5, e003768. [CrossRef] [PubMed]

103. Klerk, M.; Verhoef, P.; Clarke, R.; Blom, H.J.; Kok, F.J.; Schouten, E.G.; MTHFR Studies Collaboration Group. MTHFR 677C $\rightarrow$ T polymorphism and risk of coronary heart disease-A meta-analysis. JAMA 2002, 288, 2023-2031. [CrossRef] [PubMed]

104. Lewis, S.J.; Ebrahim, S.; Smith, G.D. Meta-analysis of MTHFR 677C $\rightarrow$ T polymorphism and coronary heart disease: Does totality of evidence support causal role for homocysteine and preventive potential of folate? Br. Med. J. 2005, 331, 1053A-1056A. [CrossRef] [PubMed]

105. Holmes, M.V.; Newcombe, P.; Hubacek, J.A.; Sofat, R.; Ricketts, S.L.; Cooper, J.; Breteler, M.M.B.; Bautista, L.E.; Sharma, P.; Whittaker, J.C.; et al. Effect modification by population dietary folate on the association between MTHFR genotype, homocysteine, and stroke risk: A meta-analysis of genetic studies and randomised trials. Lancet 2011, 378, 584-594. [CrossRef]

106. Niu, W.-Q.; You, Y.-G.; Qi, Y. Strong association of methylenetetrahydrofolate reductase gene C677T polymorphism with hypertension and hypertension-in-pregnancy in Chinese: A meta-analysis. J. Hum. Hypertens. 2012, 26, 259-267. [CrossRef] [PubMed] 
107. Yang, K.; Jia, J.; Mao, L.; Men, C.; Tang, K.; Li, Y.; Ding, H.; Zhang, Y. Methylenetetrahydrofolate reductase C677T gene polymorphism and essential hypertension: A meta-analysis of 10,415 subjects. Biomed. Rep. 2014, 2, 699-708. [CrossRef] [PubMed]

108. Horigan, G.; McNulty, H.; Ward, M.; Strain, J.J.; Purvis, J.; Scott, J.M. Riboflavin lowers blood pressure in cardiovascular disease patients homozygous for the $677 \mathrm{C} \rightarrow \mathrm{T}$ polymorphism in MTHFR. J. Hypertens. 2010, 28, 478-486. [CrossRef] [PubMed]

109. Wilson, C.P.; Ward, M.; McNulty, H.; Strain, J.J.; Trouton, T.G.; Horigan, G.; Purvis, J.; Scott, J.M. Riboflavin offers a targeted strategy for managing hypertension in patients with the MTHFR 677TT genotype: A 4-y follow-up. Am. J. Clin. Nutr. 2012, 95, 766-772. [CrossRef] [PubMed]

110. Wilson, C.P.; McNulty, H.; Ward, M.; Strain, J.J.; Trouton, T.G.; Hoeft, B.A.; Weber, P.; Roos, F.F.; Horigan, G.; McAnena, L.; et al. Blood pressure in treated hypertensive individuals with the MTHFR 677TT genotype is responsive to intervention with riboflavin: Findings of a targeted randomized trial. Hypertension 2013, 61, 1302-1308. [CrossRef] [PubMed]

111. Gjesdal, C.G.; Vollset, S.E.; Ueland, P.M.; Refsum, H.; Drevon, C.A.; Gjessing, H.K.; Tell, G.S. Plasma total homocysteine level and bone mineral density: The hordaland homocysteine study. Arch. Intern. Med. 2006, 166, 88-94. [CrossRef] [PubMed]

112. Morris, M.S.; Jacques, P.F.; Selhub, J. Relation between homocysteine and B-vitamin status indicators and bone mineral density in older Americans. Bone 2005, 37, 234-242. [CrossRef] [PubMed]

113. McLean, R.R.; Jacques, P.F.; Selhub, J.; Tucker, K.L.; Samelson, E.J.; Broe, K.E.; Hannan, M.T.; Cupples, L.A.; Kiel, D.P. Homocysteine as a predictive factor for hip fracture in older persons. N. Engl. J. Med. 2004, 350, 2042-2049. [CrossRef] [PubMed]

114. Yang, J.; Hu, X.; Zhang, Q.; Cao, H.; Wang, J.; Liu, B. Homocysteine level and risk of fracture: A meta-analysis and systematic review. Bone 2012, 51, 376-382. [CrossRef] [PubMed]

115. Van Wijngaarden, J.P.; Doets, E.L.; Szczecinska, A.; Souverein, O.W.; Duffy, M.E.; Dullemeijer, C.; Cavelaars, A.E.J.M.; Pietruszka, B.; Van't Veer, P.; Brzozowska, A.; et al. Vitamin B12, folate, homocysteine, and bone health in adults and elderly people: A systematic review with meta-analyses. J. Nutr. Metab. 2013, 2013, 486186. [CrossRef] [PubMed]

116. Cagnacci, A.; Baldassari, F.; Rivolta, G.; Arangino, S.; Volpe, A. Relation of homocysteine, folate, and vitamin B-12 to bone mineral density of postmenopausal women. Bone 2003, 33, 956-959. [CrossRef] [PubMed]

117. Tucker, K.L.; Hannan, M.T.; Qiao, N.; Jacques, P.F.; Selhub, J.; Cupples, L.A.; Kiel, D.P. Low plasma vitamin B12 is associated with lower BMD: The Framingham Osteoporosis Study. J. Bone Miner. Res. 2005, 20, 152-158. [CrossRef] [PubMed]

118. Gjesdal, C.G.; Vollset, S.E.; Ueland, P.M.; Refsum, H.; Meyer, H.E.; Tell, G.S. Plasma homocysteine, folate, and vitamin B 12 and the risk of hip fracture: The hordaland homocysteine study. J. Bone Miner. Res. 2007, 22, 747-756. [CrossRef] [PubMed]

119. Yazdanpanah, N.; Zillikens, M.C.; Rivadeneira, F.; De Jong, R.; Lindemans, J.; Uitterlinden, A.G.; Pols, H.A.P.; Van Meurs, J.B.J. Effect of dietary B vitamins on BMD and risk of fracture in elderly men and women: The Rotterdam Study. Bone 2007, 41, 987-994. [CrossRef] [PubMed]

120. Dhonukshe-Rutten, R.A.M.; De Vries, J.H.M.; De Bree, A.; Van Der Put, N.; Van Staveren, W.A.; De Groot, L.C.P.G.M. Dietary intake and status of folate and vitamin B12 and their association with homocysteine and cardiovascular disease in European populations. Eur. J. Clin. Nutr. 2009, 63, 18-30. [CrossRef] [PubMed]

121. Dai, Z.; Wang, R.; Ang, L.W.; Yuan, J.-M.; Koh, W.-P. Dietary B vitamin intake and risk of hip fracture: The Singapore Chinese Health Study. Osteoporos. Int. 2013, 24, 2049-2059. [CrossRef] [PubMed]

122. McLean, R.R.; Jacques, P.F.; Selhub, J.; Fredman, L.; Tucker, K.L.; Samelson, E.J.; Kiel, D.P.; Cupples, L.A.; Hannan, M.T. Plasma B vitamins, homocysteine, and their relation with bone loss and hip fracture in elderly men and women. J. Clin. Endocrinol. Metab. 2008, 93, 2206-2212. [CrossRef] [PubMed]

123. Rumbak, I.; Zizic, V.; Sokolic, L.; Cvijetic, S.; Kajfez, R.; Baric, I.C. Bone mineral density is not associated with homocysteine level, folate and vitamin B-12 status. Arch. Gynecol. Obstet. 2012, 285, 991-1000. [CrossRef] [PubMed]

124. Zhu, K.; Beilby, J.; Dick, I.M.; Devine, A.; Soos, M.; Prince, R.L. The effects of homocysteine and MTHFR genotype on hip bone loss and fracture risk in elderly women. Osteoporos. Int. 2009, 20, 1183-1191. [CrossRef] [PubMed] 
125. Sato, Y.; Honda, Y.; Iwamoto, J.; Kanoko, T.; Satoh, K. Effect of folate and mecobalamin on hip fractures in patients with stroke: A randomized controlled trial. JAMA 2005, 293, 1082-1088. [CrossRef] [PubMed]

126. Sawka, A.M.; Ray, J.G.; Yi, Q.; Josse, R.G.; Lonn, E. Randomized clinical trial of homocysteine level-lowering therapy and fractures. Arch. Intern. Med. 2007, 167, 2136-2139. [CrossRef] [PubMed]

127. Gommans, J.; Yi, Q.; Eikelboom, J.W.; Hankey, G.J.; Chen, C.; Rodgers, H.; VITATOPS Trial Study Group. The effect of homocysteine-lowering with B-vitamins on osteoporotic fractures in patients with cerebrovascular disease: Substudy of VITATOPS, a randomised placebo-controlled trial. BMC Geriatr. 2013, 13, 88. [CrossRef] [PubMed]

128. Enneman, A.W.; Swart, K.M.A.; Van Wijngaarden, J.P.; Van Dijk, S.C.; Ham, A.C.; Brouwer-Brolsma, E.M.; Van Der Zwaluw, N.L.; Dhonukshe-Rutten, R.A.M.; van der Cammen, T.J.M.; De Groot, L.C.P.G.M.; et al. Effect of vitamin b12 and folic acid supplementation on bone mineral density and quantitative ultrasound parameters in older people with an elevated plasma homocysteine level: B-PROOF, a randomized controlled trial. Calcif. Tissue Int. 2015, 96, 401-409. [CrossRef] [PubMed]

129. Van Wijngaarden, J.P.; Swart, K.M.A.; Enneman, A.W.; Dhonukshe-Rutten, R.A.M.; Van Dijk, S.C.; Ham, A.C.; Brouwer-Brolsma, E.M.; Van der Zwaluw, N.L.; Sohl, E.; Van Meurs, J.B.J.; et al. Effect of daily vitamin B-12 and folic acid supplementation on fracture incidence in elderly individuals with an elevated plasma homocysteine concentration: B-PROOF, a randomized controlled trial. Am. J. Clin. Nutr. 2014, 100, 1578-1586. [CrossRef] [PubMed]

130. Wolffe, A.P.; Matzke, M.A. Epigenetics: Regulation through repression. Science 1999, 286, 481-486. [CrossRef] [PubMed]

131. Robertson, K.D.; Wolffe, A.P. DNA methylation in health and disease. Nat. Rev. Genet. 2000, 1, 11-19. [CrossRef] [PubMed]

132. Kass, S.U.; Pruss, D.; Wolffe, A.P. How does DNA methylation repress transcription? Trends Genet. 1997, 13, 444-449. [CrossRef]

133. Bird, A.P.; Wolffe, A.P. Methylation-induced repression-Belts, braces, and chromatin. Cell 1999, 99, $451-454$. [CrossRef]

134. Jones, P.A.; Takai, D. The role of DNA methylation in mammalian epigenetics. Science 2001, 293, $1068-1070$. [CrossRef] [PubMed]

135. Abrahamsen, B.; Madsen, J.S.; Tofteng, C.L.; Stilgren, L.; Bladbjerg, E.M.; Kristensen, S.R.; Brixen, K.; Mosekilde, L. A common methylenetetrahydrofolate reductase (C677T) polymorphism is associated with low bone mineral density and increased fracture incidence after menopause: Longitudinal data from the Danish osteoporosis prevention study. J. Bone Miner. Res. 2003, 18, 723-729. [CrossRef] [PubMed]

136. Miyao, M.; Morita, H.; Hosoi, T.; Kurihara, H.; Inoue, S.; Hoshino, S.; Shiraki, M.; Yazaki, Y.; Ouchi, Y. Association of methylenetetrahydrofolate reductase (MTHFR) polymorphism with bone mineral density in postmenopausal Japanese women. Calcif. Tissue Int. 2000, 66, 190-194. [CrossRef] [PubMed]

137. Hong, X.; Hsu, Y.; Terwedow, H.; Tang, G.; Liu, X.; Jiang, S.; Xu, X.; Xu, X. Association of the methylenetetrahydrofolate reductase $C 677 \mathrm{~T}$ polymorphism and fracture risk in Chinese postmenopausal women. Bone 2007, 40, 737-742. [CrossRef] [PubMed]

138. Wang, H.; Liu, C. Association of MTHFR C667T polymorphism with bone mineral density and fracture risk: An updated meta-analysis. Osteoporos. Int. 2012, 23, 2625-2634. [CrossRef] [PubMed]

139. Macdonald, H.M.; McGuigan, F.E.; Fraser, W.D.; New, S.A.; Ralston, S.H.; Reid, D.M. Methylenetetrahydrofolate reductase polymorphism interacts with riboflavin intake to influence bone mineral density. Bone 2004, 35, 957-964. [CrossRef] [PubMed]

140. McLean, R.R.; Karasik, D.; Selhub, J.; Tucker, K.L.; Ordovas, J.M.; Russo, G.T.; Cupples, L.A.; Jacques, P.F.; Kiel, D.P. Association of a common polymorphism in the methylenetetrahydrofolate reductase (MTHFR) gene with bone phenotypes depends on plasma folate status. J. Bone Miner. Res. 2004, 19, 410-418. [CrossRef] [PubMed]

141. Abrahamsen, B.; Madsen, J.S.; Tofteng, C.L.; Stilgren, L.; Bladbjerg, E.M.; Kristensen, S.R.; Brixen, K.; Mosekilde, L. Are effects of MTHFR (C677T) genotype on BMD confined to women with low folate and riboflavin intake? Analysis of food records from the Danish osteoporosis prevention study. Bone 2005, 36, 577-583. [CrossRef] [PubMed] 
142. Yazdanpanah, N.; Uitterlinden, A.G.; Zillikens, M.C.; Jhamai, M.; Rivadeneira, F.; Hofman, A.; De Jonge, R.; Lindemans, J.; Pols, H.A.; Van Meurs, J.B. Low dietary riboflavin but not folate predicts increased fracture risk in postmenopausal women homozygous for the MTHFR 677 T allele. J. Bone Miner. Res. 2008, 23, 86-94. [CrossRef] [PubMed]

143. Hedden, T.; Gabrieli, J. Insights into the ageing mind: A view from cognitive neuroscience. Nat. Rev. Neurosci. 2004, 5, 87-96. [CrossRef] [PubMed]

144. Park, D.C.; Reuter-Lorenz, P. The Adaptive Brain: Aging and Neurocognitive Scaffolding. Annu. Rev. Psychol. 2009, 60, 173-196. [CrossRef] [PubMed]

145. Busse, A.; Bischkopf, J.; Riedel-Heller, S.G.; Angermeyer, M.C. Mild cognitive impairment: Prevalence and incidence according to different diagnostic criteria. Results of the Leipzig Longitudinal Study of the Aged (LEILA75+). Br. J. Psychiatry 2003, 182, 449-454. [CrossRef] [PubMed]

146. Gauthier, S.; Reisberg, B.; Zaudig, M.; Petersen, R.C.; Ritchie, K.; Broich, K.; Belleville, S.; Brodaty, H.; Bennett, D.; Chertkow, H.; et al. Mild cognitive impairment. Lancet 2006, 367, 1262-1270. [CrossRef]

147. Esiri, M.; Matthews, F.; Brayne, C.; Ince, P.; Matthews, F.; Xuereb, J.; Broome, J.; McKenzie, J.; Rossi, M.; McKeith, I.; et al. Pathological correlates of late-onset dementia in a multicentre, community-based population in England and Wales. Lancet 2001, 357, 169-175.

148. Stevens, T.; Livingston, G.; Kitchen, G.; Manela, M.; Walker, Z.; Katona, C. Islington study of dementia subtypes in the community. Br. J. Psychiatry 2002, 180, 270-276. [CrossRef] [PubMed]

149. Gorelick, P.B.; Scuteri, A.; Black, S.E.; DeCarli, C.; Greenberg, S.M.; Iadecola, C.; Launer, L.J.; Laurent, S.; Lopez, O.L.; Nyenhuis, D.; et al. Vascular contributions to cognitive impairment and dementia: A statement for healthcare professionals from the American Heart Association/American Stroke Association. Stroke 2011, 42, 2672-2713. [CrossRef] [PubMed]

150. Van der Flier, W.; Scheltens, P. Epidemiology and risk factors of dementia. J. Neurol. Neurosurg. Psychiatry 2005, 76, V2-V7. [CrossRef] [PubMed]

151. Barber, R.; Panikkar, A.; McKeith, I. Dementia with Lewy bodies: Diagnosis and management. Int. J. Geriatr. Psychiatry 2001, 16, S12-S18. [CrossRef]

152. Querfurth, H.W.; LaFerla, F.M. Alzheimer's Disease. N. Engl. J. Med. 2010, 362, 329-344. [CrossRef] [PubMed]

153. O’Brien, J.; Paling, S.; Barber, R.; Williams, E.; Ballard, C.; McKeith, I.; Gholkar, A.; Crum, W.; Rossor, M.; Fox, N. Progressive brain atrophy on serial MRI in dementia with Lewy bodies, AD, and vascular dementia. Neurology 2001, 56, 1386-1388. [CrossRef] [PubMed]

154. De Wilde, M.C.; Kamphuis, P.J.G.H.; Sijben, J.W.C.; Scheltens, P. Utility of imaging for nutritional intervention studies in Alzheimer's disease. Eur. J. Pharmacol. 2011, 668, S59-S69. [CrossRef] [PubMed]

155. Miller, J.W.; Green, R.; Mungas, D.M.; Reed, B.R.; Jagust, W.J. Homocysteine, vitamin B6, and vascular disease in AD patients. Neurology 2002, 58, 1471-1475. [CrossRef] [PubMed]

156. Smith, A.D. The worldwide challenge of the dementias: A role for B vitamins and homocysteine? Food Nutr. Bull. 2008, 29, S143-S172. [CrossRef] [PubMed]

157. Oulhaj, A.; Refsum, H.; Beaumont, H.; Williams, J.; King, E.; Jacoby, R.; Smith, A.D. Homocysteine as a predictor of cognitive decline in Alzheimer's disease. Int. J. Geriatr. Psychiatry 2010, 25, 82-90. [CrossRef] [PubMed]

158. Nie, T.; Lu, T.; Xie, L.; Huang, P.; Lu, Y.; Jiang, M. Hyperhomocysteinemia and risk of cognitive decline: A meta-analysis of prospective cohort studies. Eur. Neurol. 2014, 72, 241-248. [PubMed]

159. Beydoun, M.A.; Beydoun, H.A.; Gamaldo, A.A.; Teel, A.; Zonderman, A.B.; Wang, Y. Epidemiologic studies of modifiable factors associated with cognition and dementia: Systematic review and meta-analysis. BMC Public Health 2014, 14, 643. [CrossRef] [PubMed]

160. Horvat, P.; Gardiner, J.; Kubinova, R.; Pajak, A.; Tamosiunas, A.; Schoettker, B.; Pikhart, H.; Peasey, A.; Jansen, E.; Bobak, M. Serum folate, vitamin B-12 and cognitive function in middle and older age: The HAPIEE study. Exp. Gerontol. 2016, 76, 33-38. [CrossRef] [PubMed]

161. De Lau, L.M.L.; Refsum, H.; Smith, A.D.; Johnston, C.; Breteler, M.M.B. Plasma folate concentration and cognitive performance: Rotterdam scan study. Am. J. Clin. Nutr. 2007, 86, 728-734. [PubMed]

162. Hooshmand, B.; Solomon, A.; Kareholt, I.; Rusanen, M.; Hanninen, T.; Leiviska, J.; Winblad, B.; Laatikainen, T.; Soininen, H.; Kivipelto, M. Associations between serum homocysteine, holotranscobalamin, folate and cognition in the elderly: A longitudinal study. J. Intern. Med. 2012, 271, 204-212. [CrossRef] [PubMed] 
163. Brown, B.; Huang, M.H.; Karlamangla, A.; Seeman, T.; Kado, D. Do the effects of APOE-epsilon4 on cognitive function and decline depend upon vitamin status? MacArthur Studies of Successful Aging. J. Nutr. Health Aging 2011, 15, 196-201. [CrossRef] [PubMed]

164. Kim, J.; Stewart, R.; Kim, S.; Shin, I.; Yang, S.; Shin, H.; Yoon, J. Changes in folate, vitamin B12 and homocysteine associated with incident dementia. J. Neurol. Neurosurg. Psychiatry 2008, 79, 864-868. [CrossRef] [PubMed]

165. Erickson, K.I.; Suever, B.L.; Prakash, R.S.; Colcombe, S.J.; McAuley, E.; Kramer, A.F. Greater intake of vitamins B6 and B12 spares gray matter in healthy elderly: A voxel-based morphometry study. Brain Res. 2008, 1199, 20-26. [CrossRef] [PubMed]

166. Moorthy, D.; Peter, I.; Scott, T.M.; Parnell, L.D.; Lai, C.; Crott, J.W.; Ordovas, J.M.; Selhub, J.; Griffith, J.; Rosenberg, I.H.; et al. Status of vitamins B-12 and B-6 but not of folate, homocysteine, and the methylenetetrahydrofolate reductase C677T polymorphism are associated with impaired cognition and depression in adults. J. Nutr. 2012, 142, 1554-1560. [CrossRef] [PubMed]

167. Mooijaart, S.P.; Gussekloo, J.; Frolich, M.; Jolles, J.; Stott, D.J.; Westendorp, R.G.J.; De Craen, A.J.M. Homocysteine, vitamin B-12, and folic acid and the risk of cognitive decline in old age: The Leiden 85-Plus study. Am. J. Clin. Nutr. 2005, 82, 866-871. [PubMed]

168. Kang, J.H.; Irizarry, M.C.; Grodstein, F. Prospective study of plasma folate, vitamin B12, and cognitive function and decline. Epidemiology 2006, 17, 650-657. [CrossRef] [PubMed]

169. Clarke, R.; Birks, J.; Nexo, E.; Ueland, P.M.; Schneede, J.; Scott, J.; Molloy, A.; Evans, J.G. Low vitamin B-12 status and risk of cognitive decline in older adults. Am. J. Clin. Nutr. 2007, 86, 1384-1391. [PubMed]

170. Haan, M.N.; Miller, J.W.; Aiello, A.E.; Whitmer, R.A.; Jagust, W.J.; Mungas, D.M.; Allen, L.H.; Green, R. Homocysteine, B vitamins, and the incidence of dementia and cognitive impairment: Results from the Sacramento Area Latino Study on Aging. Am. J. Clin. Nutr. 2007, 85, 511-517. [PubMed]

171. Lildballe, D.L.; Fedosov, S.; Sherliker, P.; Hin, H.; Clarke, R.; Nexo, E. Association of cognitive impairment with combinations of vitamin B12-related parameters. Clin. Chem. 2011, 57, 1436-1443. [CrossRef] [PubMed]

172. Tangney, C.C.; Tang, Y.; Evans, D.A.; Morris, M.C. Biochemical indicators of vitamin B12 and folate insufficiency and cognitive decline. Neurology 2009, 72, 361-367. [CrossRef] [PubMed]

173. Morris, M.S.; Selhub, J.; Jacques, P.F. Vitamin B-12 and folate status in relation to decline in scores on the mini-mental state examination in the Framingham heart study. J. Am. Geriatr. Soc. 2012, 60, 1457-1464. [CrossRef] [PubMed]

174. O'Leary, F.; Allman-Farinelli, M.; Samman, S. Vitamin B12 status, cognitive decline and dementia: A systematic review of prospective cohort studies. Br. J. Nutr. 2012, 108, 1948-1961. [CrossRef] [PubMed]

175. Kado, D.M.; Karlamangla, A.S.; Huang, M.; Troen, A.; Rowe, J.W.; Selhub, J.; Seeman, T.E. Homocysteine versus the vitamins folate, B6, and B12 as predictors of cognitive function and decline in older high-functioning adults: MacArthur Studies of Successful Aging. Am. J. Med. 2005, 118, 161-167. [CrossRef] [PubMed]

176. Riggs, K.M.; Spiro, A.; Tucker, K.; Rush, D. Relations of vitamin B-12, vitamin B-6, folate, and homocysteine to cognitive performance in the normative aging study. Am. J. Clin. Nutr. 1996, 63, 306-314. [PubMed]

177. Tucker, K.L.; Qiao, N.; Scott, T.; Rosenberg, I.; Spiro, A. High homocysteine and low B vitamins predict cognitive decline in aging men: The Veterans affairs normative aging study. Am. J. Clin. Nutr. 2005, 82, 627-635. [PubMed]

178. Corrada, M.M.; Kawas, C.H.; Hallfrisch, J.; Muller, D.; Brookmeyer, R. Reduced risk of Alzheimer's disease with high folate intake: The Baltimore Longitudinal Study of Aging. Alzheimer's Dement. J. Alzheimer's Assoc. 2005, 1, 11-18. [CrossRef] [PubMed]

179. Xiu, L.; Lee, M.; Wahlqvist, M.L.; Chen, R.C.; Huang, Y.; Chen, K.; Li, D. Low and high homocysteine are associated with mortality independent of B group vitamins but interactive with cognitive status in a free-living elderly cohort. Nutr. Res. 2012, 32, 928-939. [CrossRef] [PubMed]

180. Wald, D.S.; Kasturiratne, A.; Simmonds, M. Effect of folic acid, with or without other B vitamins, on cognitive decline: Meta-analysis of randomized trials. Am. J. Med. 2010, 123, 522-527. [CrossRef] [PubMed]

181. Clarke, R.; Bennett, D.; Parish, S.; Lewington, S.; Skeaff, M.; Eussen, S.J.P.M.; Lewerin, C.; Stott, D.J.; Armitage, J.; Hankey, G.J.; et al. Effects of homocysteine lowering with B vitamins on cognitive aging: Meta-analysis of 11 trials with cognitive data on 22,000 individuals. Am. J. Clin. Nutr. 2014, 100, 657-666. [CrossRef] [PubMed] 
182. McCaddon, A.; Miller, J.W. Assessing the association between homocysteine and cognition: Reflections on Bradford Hill, meta-analyses, and causality. Nutr. Rev. 2015, 73, 723-735. [CrossRef] [PubMed]

183. Smith, D.; de Jager, C.; Refsum, H.; Rosenberg, I.H. B-vitamin trials meta-analysis: Less than meets the eye. Am. J. Clin. Nutr. 2015, 101, 415-416. [CrossRef] [PubMed]

184. Garrard, P.; Jacoby, R. Homocysteine lowering, B vitamins, and cognitive aging. Am. J. Clin. Nutr. 2015, 101, 414-415. [CrossRef] [PubMed]

185. Van der Zwaluw, N.L.; Dhonukshe-Rutten, R.A.M.; Van Wijngaarden, J.P.; Brouwer-Brolsma, E.M.; Van De Rest, O.; In't Veld, P.H.; Enneman, A.W.; Van Dijk, S.C.; Ham, A.C.; Swart, K.M.A.; et al. Results of 2-year vitamin B treatment on cognitive performance: Secondary data from an RCT. Neurology 2014, 83, 2158-2166. [CrossRef] [PubMed]

186. Durga, J.; Van Boxtel, M.P.J.; Schouten, E.G.; Kok, F.J.; Jolles, J.; Katan, M.B.; Verhoef, P. Effect of 3-year folic acid supplementation on cognitive function in older adults in the FACIT trial: A randomised, double blind, controlled trial. Lancet 2007, 369, 208-216. [CrossRef]

187. Walker, J.G.; Batterham, P.J.; Mackinnon, A.J.; Jorm, A.F.; Hickie, I.; Fenech, M.; Kljakovic, M.; Crisp, D.; Christensen, H. Oral folic acid and vitamin B-12 supplementation to prevent cognitive decline in community-dwelling older adults with depressive symptoms-The beyond ageing project: A randomized controlled trial. Am. J. Clin. Nutr. 2012, 95, 194-203. [CrossRef] [PubMed]

188. Douaud, G.; Refsum, H.; de Jager, C.A.; Jacoby, R.; Nichols, T.E.; Smith, S.M.; Smith, A.D. Preventing Alzheimer's disease-related gray matter atrophy by B-vitamin treatment. Proc. Natl. Acad. Sci. USA 2013, 110, 9523-9528. [CrossRef] [PubMed]

189. Kwok, T.; Lee, J.; Law, C.B.; Pan, P.C.; Yung, C.Y.; Choi, K.C.; Lam, L.C. A randomized placebo controlled trial of homocysteine lowering to reduce cognitive decline in older demented people. Clin. Nutr. 2011, 30, 297-302. [CrossRef] [PubMed]

190. Kang, J.H.; Cook, N.; Manson, J.; Buring, J.E.; Albert, C.M.; Grodstein, F. A trial of B vitamins and cognitive function among women at high risk of cardiovascular disease. Am. J. Clin. Nutr. 2008, 88, 1602-1610. [CrossRef] [PubMed]

191. McMahon, J.A.; Green, T.J.; Skeaff, C.M.; Knight, R.G.; Mann, J.I.; Williams, S.M. A controlled trial of homocysteine lowering and cognitive performance. N. Engl. J. Med. 2006, 354, 2764-2772. [CrossRef] [PubMed]

192. Balk, E.M.; Raman, G.; Tatsioni, A.; Chung, M.; Lau, J.; Rosenberg, I.H. Vitamin B-6, B-12, and folic acid supplementation and cognitive function-A systematic review of randomized trials. Arch. Intern. Med. 2007, 167, 21-30. [CrossRef] [PubMed]

193. Brady, C.B.; Gaziano, J.M.; Cxypoliski, R.A.; Guarino, P.D.; Kaufman, J.S.; Warren, S.R.; Hartigan, P.; Goldfarb, D.S.; Jamison, R.L. Homocysteine lowering and cognition in CKD: The Veterans Affairs homocysteine study. Am. J. Kidney Dis. 2009, 54, 440-449. [CrossRef] [PubMed]

194. Ford, A.H.; Flicker, L.; Alfonso, H.; Thomas, J.; Clarnette, R.; Martins, R.; Almeida, O.P. Vitamins B(12), B(6), and folic acid for cognition in older men. Neurology 2010, 75, 1540-1547. [CrossRef] [PubMed]

195. De Jager, C.A.; Oulhaj, A.; Jacoby, R.; Refsum, H.; Smith, A.D. Cognitive and clinical outcomes of homocysteine-lowering B-vitamin treatment in mild cognitive impairment: A randomized controlled trial. Int. J. Geriatr. Psychiatry 2012, 27, 592-600. [CrossRef] [PubMed]

196. Smith, A.D.; Smith, S.M.; de Jager, C.A.; Whitbread, P.; Johnston, C.; Agacinski, G.; Oulhaj, A.; Bradley, K.M.; Jacoby, R.; Refsum, H. Homocysteine-lowering by B vitamins slows the rate of accelerated brain atrophy in mild cognitive impairment: A randomized controlled trial. PLoS ONE 2010, 5, e1224. [CrossRef] [PubMed]

197. Tsai, S.; Hong, C.; Yeh, H.; Liou, Y.; Yang, A.C.; Liu, M.; Hwang, J. Heterozygote advantage of the MTHFR C677T Polymorphism on specific cognitive performance in elderly Chinese males without dementia. Dement. Geriatr. Cogn. Disord. 2011, 32, 159-163. [CrossRef] [PubMed]

198. Ford, A.H.; Flicker, L.; Hankey, G.J.; Norman, P.; van Bockxmeer, F.M.; Almeida, O.P. Homocysteine, methylenetetrahydrofolate reductase $C 677 T$ polymorphism and cognitive impairment: The health in men study. Mol. Psychiatry 2012, 17, 559-566. [CrossRef] [PubMed]

199. Rai, V. Methylenetetrahydrofolate Reductase (MTHFR) C677T Polymorphism and Alzheimer Disease Risk: A meta-analysis. Mol. Neurobiol. 2016. [CrossRef] [PubMed] 
200. Liu, H.; Yang, M.; Li, G.; Qiu, Y.; Zheng, J.; Du, X.; Wang, J.; Liu, R. The MTHFR C677T polymorphism contributes to an increased risk for vascular dementia: A meta-analysis. J. Neurol. Sci. 2010, 294, 74-80. [CrossRef] [PubMed]

201. Hua, Y.; Zhao, H.; Kong, Y.; Ye, M. Association between the MTHFR Gene and Alzheimer's Disease: A meta-analysis. Int. J. Neurosci. 2011, 121, 462-471. [CrossRef] [PubMed]

202. Hooshmand, B.; Mangialasche, F.; Kalpouzos, G.; Solomon, A.; Kareholt, I.; Smith, A.D.; Refsum, H.; Wang, R.; Muhlmann, M.; Ertl-Wagner, B.; et al. Association of vitamin B12, folate, and sulfur amino acids with brain magnetic resonance imaging measures in older adults: A longitudinal population-based study. JAMA Psychiatry 2016, 73, 606-613. [CrossRef] [PubMed]

203. Kobe, T.; Witte, A.V.; Schnelle, A.; Grittner, U.; Tesky, V.A.; Pantel, J.; Schuchardt, J.P.; Hahn, A.; Bohlken, J.; Rujescu, D.; et al. Vitamin B-12 concentration, memory performance, and hippocampal structure in patients with mild cognitive impairment. Am. J. Clin. Nutr. 2016, 103, 1045-1054. [CrossRef] [PubMed]

204. Vogiatzoglou, A.; Refsum, H.; Johnston, C.; Smith, S.M.; Bradley, K.M.; De Jager, C.; Budge, M.M.; Smith, A.D. Vitamin B12 status and rate of brain volume loss in community-dwelling elderly. Neurology 2008, 71, 826-832. [CrossRef] [PubMed]

205. Tangney, C.C.; Aggarwal, N.T.; Li, H.; Wilson, R.S.; Decarli, C.; Evans, D.A.; Morris, M.C. Vitamin B12, cognition, and brain MRI measures: A cross-sectional examination. Neurology 2011, 77, 1276-1282. [CrossRef] [PubMed]

206. De Lau, L.M.L.; Smith, A.D.; Refsum, H.; Johnston, C.; Breteler, M.M.B. Plasma vitamin B12 status and cerebral white-matter lesions. J. Neurol. Neurosurg. Psychiatry 2009, 80, 149-157. [CrossRef] [PubMed]

207. Gallucci, M.; Zanardo, A.; Bendini, M.; Di Paola, F.; Boldrini, P.; Grossi, E. Serum folate, homocysteine, brain atrophy, and auto-CM system: The Treviso Dementia (TREDEM) study. J. Alzheimer's Dis. 2014, 38, 581-587.

208. Maestu, F.; Campo, P.; Del Rio, D.; Moratti, S.; Gil-Gregorio, P.; Fernandez, A.; Capilla, A.; Ortiz, T. Increased biomagnetic activity in the ventral pathway in mild cognitive impairment. Clin. Neurophysiol. 2008, 119, 1320-1327. [CrossRef] [PubMed]

209. Lipton, S.A.; Kim, W.K.; Choi, Y.B.; Kumar, S.; DEmilia, D.M.; Rayudu, P.V.; Arnelle, D.R.; Stamler, J.S. Neurotoxicity associated with dual actions of homocysteine at the N-methyl-D-aspartate receptor. Proc. Natl. Acad. Sci. USA 1997, 94, 5923-5928. [CrossRef] [PubMed]

210. Kennedy, B.P.; Bottiglieri, T.; Arning, E.; Ziegler, M.G.; Hansen, L.A.; Masliah, E. Elevated $S$-adenosylhomocysteine in Alzheimer brain: Influence on methyltransferases and cognitive function. J. Neural Transm. 2004, 111, 547-567. [CrossRef] [PubMed]

211. Fuso, A.; Seminara, L.; Cavallaro, R.A.; D'Anselmi, F.; Scarpa, S. S-adenosylmethionine/homocysteine cycle alterations modify DNA methylation status with consequent deregulation of PS1 and BACE and beta-amyloid production. Mol. Cell. Neurosci. 2005, 28, 195-204. [CrossRef] [PubMed]

212. Duthie, S.J.; Narayanan, S.; Brand, G.M.; Pirie, L.; Grant, G. Impact of folate deficiency on DNA stability. J. Nutr. 2002, 132, 2444S-2449S. [PubMed]

213. Kruman, I.I.; Kumaravel, T.S.; Lohani, A.; Pedersen, W.A.; Cutler, R.G.; Kruman, Y.; Haughey, N.; Lee, J.; Evans, M.; Mattson, M.P. Folic acid deficiency and homocysteine impair DNA repair in hippocampal neurons and sensitize them to amyloid toxicity in experimental models of Alzheimer's disease. J. Neurosci. 2002, 22, 1752-1762. [PubMed]

214. Kruman, I.I.; Culmsee, C.; Chan, S.L.; Mattson, M.P. Folic acid deficiency and homocysteine induce neuronal apoptosis. Soc. Neurosci. 2000, 26, 93.

215. Selhub, J.; Troen, A.; Rosenberg, I.H. B vitamins and the aging brain. Nutr. Rev. 2010, 68, S112-S118. [CrossRef] [PubMed]

216. Bernstein, A.L. Vitamin B6 in clinical neurology. Ann. N. Y. Acad. Sci. 1990, 585, 250-260. [CrossRef] [PubMed]

217. Tracy, R.P. Emerging relationships of inflammation, cardiovascular disease and chronic diseases of aging. Int. J. Obes. 2003, 27, S29-S34. [CrossRef] [PubMed]

218. Dik, M.; Ferrucci, L. Chronic inflammation and common geriatric syndromes: The longitudinal aging study Amsterdam. Gerontologist 2005, 45, 654-656.

219. Van Oijen, M.; de Jong, F.J.; Witteman, J.C.M.; Hofman, A.; Koudstaal, P.J.; Breteler, M.M.B. Atherosclerosis and risk for dementia. Ann. Neurol. 2007, 61, 403-410. [CrossRef] [PubMed] 
220. Kim, G.; Kim, C.; Park, J.; Lee, K.; Park, C. Effects of vitamin B12 on cell proliferation and cellular alkaline phosphatase activity in human bone marrow stromal osteoprogenitor cells and UMR106 osteoblastic cells. Metabolism 1996, 45, 1443-1446. [CrossRef]

221. Masse, P.; Delvin, E.; Hauschka, P.; Donovan, S.; Grynpas, M.; Mahuren, J.; Watkins, B.; Howell, D. Perturbations in factors that modulate osteoblast functions in vitamin B6 deficiency. Can. J. Physiol. Pharmacol. 2000, 78, 904-911. [CrossRef] [PubMed]

222. Holstein, J.H.; Herrmann, M.; Splett, C.; Herrmann, W.; Garcia, P.; Histing, T.; Klein, M.; Kurz, K.; Siebel, T.; Pohlemann, T.; et al. High bone concentrations of homocysteine are associated with altered bone morphology in humans. Br. J. Nutr. 2011, 106, 378-382. [CrossRef] [PubMed]

223. Wei, I.L.; Huang, Y.H.; Wang, G.S. Vitamin B-6 deficiency decreases the glucose utilization in cognitive brain structures of rats. J. Nutr. Biochem. 1999, 10, 525-531. [CrossRef]

224. Fuso, A.; Nicolia, V.; Cavallaro, R.A.; Ricceri, L.; D’Anselmi, F.; Coluccia, P.; Calamandrei, G.; Scarpa, S. B-vitamin deprivation induces hyperhomocysteinemia and brain $S$-adenosylhomocysteine, depletes brain $S$-adenosylmethionine, and enhances PS1 and BACE expression and amyloid-beta deposition in mice. Mol. Cell. Neurosci. 2008, 37, 731-746. [CrossRef] [PubMed]

225. Wang, B.B.; Jin, F.; Kan, R.; Ji, S.; Zhang, C.F.; Lu, Z.P.; Zheng, C.G.; Yang, Z.; Wang, L. Association of MTHFR gene polymorphism C677T with susceptibility to late-onset Alzheimer's disease. J. Mol. Neurosci. 2005, 27, 23-27. [CrossRef]

226. Bi, X.; Zhao, H.; Zhang, Z.; Zhang, J. Association of RFC1 A80G and MTHFR C677T polymorphisms with Alzheimer's disease. Neurobiol. Aging 2009, 30, 1601-1607. [CrossRef] [PubMed]

227. Global Progress. Available online: http://ffinetwork.org/global_progress/index.php (accessed on 1 September 2016).

228. Williams, J.; Mai, C.T.; Mulinare, J.; Isenburg, J.; Flood, T.J.; Ethen, M.; Frohnert, B.; Kirby, R.S. Updated estimates of neural tube defects prevented by mandatory folic Acid fortification-United States, 1995-2011. MMWR Morb. Mortal. Wkly. Rep. 2015, 64, 1-5. [PubMed]

229. Jacques, P.F.; Selhub, J.; Bostom, A.G.; Wilson, P.W.F.; Rosenberg, I.H. The effect of folic acid fortification on plasma folate and total homocysteine concentrations. N. Engl. J. Med. 1999, 340, 1449-1454. [CrossRef] [PubMed]

230. Morris, M.S.; Jacques, P.F.; Rosenberg, I.H.; Selhub, J. Folate and vitamin B-12 status in relation to anemia, macrocytosis, and cognitive impairment in older Americans in the age of folic acid fortification. Am. J. Clin. Nutr. 2007, 85, 193-200. [PubMed]

231. Bailey, R.L.; Looker, A.C.; Lu, Z.; Fan, R.; Eicher-Miller, H.A.; Fakhouri, T.H.; Gahche, J.J.; Weaver, C.M.; Mills, J.L. B-vitamin status and bone mineral density and risk of lumbar osteoporosis in older females in the United States. Am. J. Clin. Nutr. 2015, 102, 687-694. [CrossRef] [PubMed]

232. Hoey, L.; McNulty, H.; Askin, N.; Dunne, A.; Ward, M.; Pentieva, K.; Strain, J.J.; Molloy, A.M.; Flynn, C.A.; Scott, J.M. Effect of a voluntary food fortification policy on folate, related B vitamin status, and homocysteine in healthy adults. Am. J. Clin. Nutr. 2007, 86, 1405-1413. [PubMed]

233. Hopkins, S.M.; Gibney, M.J.; Nugent, A.P.; McNulty, H.; Molloy, A.M.; Scott, J.M.; Flynn, A.; Strain, J.J.; Ward, M.; Walton, J.; et al. Impact of voluntary fortification and supplement use on dietary intakes and biomarker status of folate and vitamin B-12 in Irish adults. Am. J. Clin. Nutr. 2015, 101, 1163-1172. [CrossRef] [PubMed]

234. Institute of Medicine Panel. Dietary Reference Intake: Thiamin, Riboflavin, Niacin, Vitamin B6, Vitamin B12, Pantothenic acid, Biotin and Choline; National Academies Press: Washington, DC, USA, 2000; pp. 306-356.

235. EFSA NDA Panel. Scientific opinion on dietary reference values for cobalamin (Vitamin B12). EFSA J. 2015, 13, 4150.

236. Carmel, R.; Green, R.; Rosenblatt, D.S.; Watkins, D. Update on cobalamin, folate, and homocysteine. Hematol. Am. Soc. 2003, 1, 62-81. [CrossRef]

237. Mills, J.L.; Von Kohorn, I.; Conley, M.R.; Zeller, J.A.; Cox, C.; Williamson, R.E.; Dufour, D.R. Low vitamin B-12 concentrations in patients without anemia: The effect of folic acid fortification of grain. Am. J. Clin. Nutr. 2003, 77, 1474-1477. [PubMed]

238. Mills, J.L.; Carter, T.C.; Scott, J.M.; Troendle, J.F.; Gibney, E.R.; Shane, B.; Kirke, P.N.; Ueland, P.M.; Brody, L.C.; Molloy, A.M. Do high blood folate concentrations exacerbate metabolic abnormalities in people with low vitamin B-12 status? Am. J. Clin. Nutr. 2011, 94, 495-500. [CrossRef] [PubMed] 
239. Qi, Y.; Hamner, H.; Pfeiffe, C.; Berry, R. The prevalence of low serum vitamin B-12 status in the absence of anemia or macrocytosis did not increase among older U.S. adults after mandatory folic acid fortification. J. Nutr. 2014, 144, 170-176. [CrossRef] [PubMed]

240. Selhub, J.; Morris, M.S.; Jacques, P.F.; Rosenberg, I.H. Folate-vitamin B-12 interaction in relation to cognitive impairment, anemia, and biochemical indicators of vitamin B-12 deficiency. Am. J. Clin. Nutr. 2009, 89, 702s-706s. [CrossRef] [PubMed]

241. Moore, E.M.; Ames, D.; Mander, A.G.; Carne, R.P.; Brodaty, H.; Woodward, M.C.; Boundy, K.; Ellis, K.A.; Bush, A.I.; Faux, N.G.; et al. Among vitamin B12 deficient older people, high folate levels are associated with worse cognitive function: Combined data from three cohorts. J. Alzheimer's Dis. 2014, 39, 661-668.

242. Clarke, R.; Sherliker, P.; Hin, H.; Molloy, A.M.; Nexo, E.; Ueland, P.M.; Emmens, K.; Scott, J.M.; Evans, J.G. Folate and vitamin B12 status in relation to cognitive impairment and anaemia in the setting of voluntary fortification in the UK. Br. J. Nutr. 2008, 100, 1054-1059. [CrossRef] [PubMed]

243. Doets, E.L.; Ueland, P.M.; Tell, G.S.; Vollset, S.E.; Nygard, O.K.; Van't Veer, P.; De Groot, L.C.P.G.M.; Nurk, E.; Refsum, H.; Smith, A.D.; et al. Interactions between plasma concentrations of folate and markers of vitamin $\mathrm{B}(12)$ status with cognitive performance in elderly people not exposed to folic acid fortification: The Hordaland Health Study. Br. J. Nutr. 2014, 111, 1085-1095. [CrossRef] [PubMed]

244. National Toxicology Program. Identifying Research Needs for Safe Use of High Intakes of Folic Acid. 2015. Available online: https://ntp.niehs.nih.gov/ntp/ohat/folicacid/ntpfolicacid_approach_508.pdf (accessed on 1 August 2016).

245. Ebbing, M.; Bonaa, K.H.; Nygard, O.; Arnesen, E.; Ueland, P.M.; Nordrehaug, J.E.; Rasmussen, K.; Njolstad, I.; Refsum, H.; Nilsen, D.W.; et al. Cancer incidence and mortality after treatment with folic acid and vitamin B-12. JAMA 2009, 302, 2119-2126. [CrossRef] [PubMed]

246. Figueiredo, J.C.; Grau, M.V.; Haile, R.W.; Sandler, R.S.; Summers, R.W.; Bresalier, R.S.; Burke, C.A.; McKeown-Eyssen, G.E.; Baron, J.A. Folic acid and risk of prostate cancer: Results from a randomized clinical trial. J. Natl. Cancer Inst. 2009, 101, 432-435. [CrossRef] [PubMed]

247. Mason, J.B. Folate consumption and cancer risk: A confirmation and some reassurance, but we're not out of the woods quite yet. Am. J. Clin. Nutr. 2011, 94, 965-966. [CrossRef] [PubMed]

248. Report to CMO on Folic Acid and Colorectal Cancer. Available online: https:/ /www.gov.uk/government/ publications/sacn-report-to-cmo-on-folic-acid-and-colorectal-cancer-risk (accessed on 24 August 2016).

249. Troen, A.M.; Mitchell, B.; Sorensen, B.; Wener, M.H.; Johnston, A.; Wood, B.; Selhub, J.; McTiernan, A.; Yasui, Y.; Oral, E.; et al. Unmetabolized folic acid in plasma is associated with reduced natural killer cell cytotoxicity among postmenopausal women. J. Nutr. 2006, 136, 189-194. [PubMed]

(C) 2016 by the authors; licensee MDPI, Basel, Switzerland. This article is an open access article distributed under the terms and conditions of the Creative Commons Attribution (CC-BY) license (http://creativecommons.org/licenses/by/4.0/). 